\title{
1,2-benzenedicarboxylic acid, bis (2-methyl propyl) ester isolated from Onosma bracteata Wall. inhibits MG-63 cells proliferation via Akt-p53-cyclin pathway
}

\section{Ajay Kumar}

Guru Nanak Dev University

\section{Sandeep Kaur}

Guru Nanak Dev University

\section{Sukhvinder Dhiman}

Guru Nanak Dev University

\section{Prithvi Pal Singh}

CSIR-IHBT: Institute of Himalayan Bioresource Technology CSIR

\section{Sharad Thakur}

CSIR-IHBT: Institute of Himalayan Bioresource Technology CSIR

\section{Upendra Sharma}

CSIR-IHBT: Institute of Himalayan Bioresource Technology CSIR

\section{Subodh Kumar}

Guru Nanak Dev University

Satwinderjeet Kaur ( $\sim$ sjkaur2011@gmail.com )

Guru Nanak Dev University

\section{Research Article}

Keywords: Antioxidant, Apoptosis, Cytotoxic potential, Onosma bracteata, Reactive oxygen species

Posted Date: June 4th, 2021

DOI: https://doi.org/10.21203/rs.3.rs-182390/v1

License: (c) (1) This work is licensed under a Creative Commons Attribution 4.0 International License. Read Full License 
1,2-benzenedicarboxylic acid, bis (2-methyl propyl) ester isolated from Onosma bracteata Wall. inhibits MG-63 cells proliferation via Akt-p53-cyclin pathway

3 7 (India)

Ajay Kumar ${ }^{\mathrm{a}}$, Sandeep Kaur ${ }^{\mathrm{a}}$, Sukhvinder Dhiman ${ }^{\mathrm{b}}$, Prithvi Pal Singh ${ }^{\mathrm{c}, \mathrm{d}}$, Sharad Thakur ${ }^{\mathrm{e}}$, Upendra Sharma ${ }^{\mathrm{c}, \mathrm{d}}$, Subodh $\operatorname{Kumar}^{\mathrm{b}}$ and Satwinderjeet Kaur ${ }^{\mathrm{a} *}$

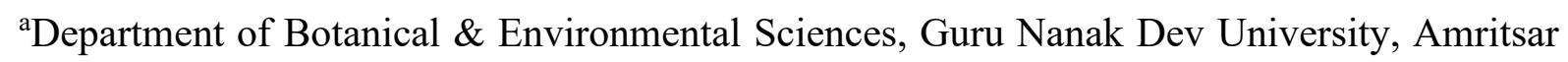

${ }^{b}$ Department of Chemistry, Guru Nanak Dev University, Amritsar (India)

${ }^{c}$ Chemical Technology Division, CSIR-IHBT, Palampur (India)

${ }^{\mathrm{d} A c a d e m y}$ of Scientific and Innovative Research (AcSIR), Ghaziabad-201002, India

eBiotechnology Division, COVID-19 Project, CSIR-IHBT, Palampur (India)

\section{*Corresponding Author}

Dr. Satwinderjeet Kaur, Professor,

Department of Botanical \& Environmental Sciences,

Guru Nanak Dev University,

Amritsar-143005, Punjab (India)

Email: Correspondence: satwinderjeet.botenv@gndu.ac.in; sjkaur2011@gmail.com

Contact: $+91-8283808508$

List of abbreviations: Apaf-1: apoptotic protease activating factor 1; Bcl-2: b cell lymphoma 2; BHT: butylated hydroxytoluene; CDK2: Cyclin-dependent kinase 2; CLMS: Confocal Laser Scanning Microscopy; COX-2: cyclooxygenase-2; $\mathrm{CO}_{2}$ : carbon dioxide; DCFH-DA: 2',7'dichlorofluorescein diacetate; DIBP: Di-isobutyl phthalate; DMEM: Dulbecco's Modified Eagle Medium; DMSO: Dimethyl sulfoxide; EA: early apoptosis; EDTA: ethylenediamine tetra acetic acid; FBS: Fetal bovine serum; FTIR: fourier-transform infrared spectroscopy; HRMS: High-resolution mass spectroscopy; KCL: potassium chloride; LA: late apoptosis; L: live; MG-63: human osteosarcoma cells; MMP: mitochondria membrane potential; MTT: 3- 
(4,5-dimethythiazol-2-yl)-2,5-diphenyl tetrazolium bromide; $\mathrm{N}$ : necrotic; NADH: nicotinamide adenine dinucleotide; NBT: nitro blue tetrazolium; NCCS: National Centre for Cell Science; NFкB: nuclear factor-kappa B; NMR: Nuclear magnetic Resonance; OS: Osteosarcoma; p-Akt: phosphorylated-Akt; PMS: phenazine methosulfate; PVDF: polyvinylidene fluoride; PAGE: polyacrylamide gel electrophoresis; PBS: phosphate buffer saline; RIN: residue interaction networks; RING: residue interaction network generator; RT: room temperature; RT-qPCR: quantitative real-time polymerase chain reaction; RMSD: root mean square deviation; ROS: reactive oxygen species; Rh123: rhodamine123; rpm: revolutions per minute; SDS: sodium dodecyl sulphate; SDS page: dodecyl sulphate-polyacrylamide gel electrophoresis; TBA: 2-thiobarbituric acid; TCA: trichloroacetic acid; TLC: thin layer chromatography; WB: western blotting.

\section{Abstract}

Onosma bracteata Wall. (Boraginaceae family) is one of the important constituents of Ayurvedic drugs which enhance immunity. Among all the fractions isolated from O. bracteata, ethyl acetate fraction (Obea) showed good antioxidant activity in Superoxide radical scavenging assay and Lipid peroxidation assay with $\mathrm{EC}_{50}$ value of 95.12 and $80.67 \mu \mathrm{g} / \mathrm{ml}$, respectively. Silica gel column chromatography of Obea yielded ObD1 fraction which was characterized as Di-isobutyl phthalate (DIBP) using NMR, FTIR and HRMS spectroscopic techniques. DIBP showed antiproliferative activity in human osteosarcoma MG-63, human neuroblastoma IMR-32 and A549 cell lines with GI50 value of 37.53, 56.05 and $47.12 \mu \mathrm{M}$, respectively, in MTT assay. In Flow cytometric studies, DIBP has shown disruption of mitochondrial membrane potential (MMP) and enhancement of ROS, indicating the apoptosis induction. The cells were found to be delayed at $\mathrm{G}_{0} / \mathrm{G}_{1}$ phase which might be due to the downregulation of Cyclin E and CDK2 as shown in RT-PCR studies. Western blotting analysis revealed an increased expression of p53, caspase 3 and caspase 9 and downregulation of p-NF- 
$\mathrm{kB}, \mathrm{p}-\mathrm{Akt}$ and Bcl-xl. Molecular docking studies also displayed the interaction of DIBP with p53 $(-151.13 \mathrm{kcal} / \mathrm{mol})$ and CDK1 $(-133.96 \mathrm{kcal} / \mathrm{mol})$. Thus, DIBP has exhibited great potential as chemopreventive/chemotherapeutic agent against osteosarcoma.

Keywords: Antioxidant, Apoptosis, Cytotoxic potential, Onosma bracteata, Reactive oxygen species

\section{Introduction}

Cancer is a complicated disease in which cells multiply and grow uncontrollably due to altered signaling pathways in different tumor types. Osteosarcoma (OS) is a primary malignant bone sarcoma that occurs in children and adolescents with $\sim 10 \%$ of OS in individuals older than 60 years (Durfee et al., 2016). Corre et al., 2020 reported the yearly occurrence of osteosarcoma as 1 to 3 cases per million in 15-19 years of age. OS generally develops via unbalanced cell proliferation, dysregulation of cell cycle, mutations in DNA and around 70\% of osteosarcoma cases showed chromosomal aberrations (Misaghi et al., 2018). Numerous types of treatment strategies are available for dealing with carcinogenesis such as chemotherapy, immunotherapy, radiation therapy, targeted therapy and gene therapy which help to cure cancer still these strategies have severe side effects (Siamof et al., 2020). So, there is an urgent need to develop effective treatment strategies to prevent cancer. Although, there are a variety of modern medicine options available for treating cancer, still these strategies have limitations such as re-occurrence, metastasis, low success rate and several side effects (Bielack et al., 2009; Huang et al., 2017). The cancer cells undergo incessant mutations that reduce the effectiveness of cancer-targeting approaches (Loeb and Loeb 2000). Moreover, oxidative stress is one of the factors which trigger cancer progression (Milkovic et al., 2017). However, generation of ROS may lead to oxidative stress that interrupts redox signaling and causes 
damage to biomolecules (Kim et al., 2015). Wang et al., 2017 demonstrated the crucial role of mitochondrial-dependent pathways in ROS-mediated apoptosis. Manifestation of apoptosis includes cell shrinkage, nuclear condensation and DNA fragmentation (Saraste and Pulkki, 2000; Joselin et al., 2006). Existing chemo-therapeutic medication does not show a significant effect on cancer cells (Bao et al., 2019). Cancer cells can be metastasized to the distant parts of the body organs, even after the tumor is completely removed from the primary site (Li et al., 2018). Therefore, considering the above-mentioned circumstances, the challenge is to selectively eliminate cancer-promoting cells via tumor-specific biomarkers that are involved in carcinogenesis. Natural compounds have been recognized as valuable sources of drugs, especially for cancer treatment (Lin et al., 2020). Around 60\% of anticancer drugs, explored clinically, have been isolated from natural products (Elias et al., 2019). Phytoconstituents that exhibit antioxidant and anticancer properties, act via molecular mechanisms targeting receptors and enzymes in signal transduction pathways associated with cell proliferation (Bcl-2), inflammation (p-NF-kB), apoptosis (p53, caspases) and multidrug resistance (Sun et al., 2019; Choudhari et al., 2020). Anchusa italica (Boraginaceae) showed various types of biological activities due to the presence of phytoconstituents including di-isobutyl phthalate (Kazemi, 2013).

Onosma bracteata Wall. (Boraginaceae) is an important medicinal herb which is largely found in high altitude areas of India and Nepal (Ved et al., 2016). It is used in the synthesis of various drugs in Unani and Ayurvedic medicinal systems due to its beneficial health effects (Zeb et al., 2015). O. bracteata has been shown to possess various types of pharmacological properties (Kumar et al., 2013; Albaqami et al., 2018; Farooq et al., 2019). Ethyl acetate fraction (Obea) from O. bracteata was demonstrated to effectively inhibit the proliferation of MG-63 cells (Kumar et al., 2020). The present study is planned to isolate the phytoconstituent(s) responsible for the anticancer potential and aims at the isolation of effective 
active compound(s) from Obea fraction with excellent anticancer potential. Silica gel Column chromatography of Obea fraction yielded 1,2-benzene dicarboxylic acid, bis (2-methyl propyl) ester, also known as di-isobutyl phthalate (DIBP), which possess good anti-proliferative activity and was further studied for its role in induction of apoptosis in MG-63 cells. This is the first study to report the anticancer potential of DIBP against osteosarcoma.

\section{Materials and Methods}

\section{Chemicals and Reagents}

Dulbecco's modified Eagle's medium (DMEM), Hoechst 33342, Fluoromount, 2',7'Dichlorodihydrofluorescein diacetate (DCFH-DA), and Rhodamine-123 and Fetal Bovine Serum (FBS) were purchased from Sigma (St. Louis, MO, USA). 3-(4,5-dimethylthiazol-2-yl)2,5-diphenyl tetrazolium bromide (MTT) and trypsin were procured from Hi-media Pvt. Limited, Mumbai (India). Rabbit monoclonal Bcl-xl, p-53, p-NF-кB, Caspase3 and Caspase9 antibodies, and anti-rabbit- HRP secondary antibody were obtained from Cell Signaling Technology, Danvers, MA, USA. (PVDF) membrane (MDI, Ambala). RT-PCR chemical kit, was purchased from Bio-Rad, California, USA. The BD Cycletest plus DNA Kit was from BD Biosciences, San Jose, CA, USA. Chemicals and reagents of analytical (AR) grade were used to perform the experiments.

\section{Plant procurement, identification and authentication of plant material}

The plant $O$. bracteata, with accession no. GAZ-03, was purchased from the Herbal Health Research Consortium (HHRC) Pvt. Ltd. Amritsar, Punjab (India) associated to National Medicinal Plant Board (NMPB), Ministry of AYUSH, Government of India. The plant material was deposited in the Herbarium of the Department of Botanical and Environmental Sciences, Guru Nanak Dev University, Amritsar (Accession no: 7576). 


\section{Extraction and fractionation}

The plant material was washed with distilled water and kept at $40^{\circ} \mathrm{C}$. The dried plant was coarse grinded $(2 \mathrm{~kg})$ and soaked in ethanol $(80 \%)$ by maceration method. The supernatant was decanted off into a flask and ethanol was distilled using Rotavapor (Buchi Rotavapor R-210, Switzerland) to get Ethanolic extract (Obeth). Further, fractionation was done using different organic solvents with increasing polarity, viz. hexane to yield Obhex fraction (6g), chloroform to yield $\mathrm{Obcl}$ fraction $(10 \mathrm{~g})$, ethyl acetate to yield Obea $(7 \mathrm{~g}), \mathrm{n}$ - butanol to yield $O b b u(15 \mathrm{~g})$ and remaining extract to yield Obaq fraction (18g) (Flow chart 1).

\section{Column Chromatography of the Obea fraction}

\section{Isolation of OBD1}

The slurry of Obea (3 $\mathrm{g}$ ) of O. bracteata was packed in a column with silica (mesh size 60-120) using $n$-hexane. The gradient of $n$-hexane (Hex): ethyl acetate (EtAc) was used as eluent. With increasing polarity, a total of 50 fractions of $50 \mathrm{ml}$ each were collected and concentrated based on their thin layer chromatography (TLC) results. Pooled fractions 11-15 were further subjected to preparatory TLC with a gradient eluent of Hex: EtAc $(9: 1),(8: 2)$, (7:3), (6:4) and (5:5) (Flow chart 2). The blue fluorescence single spot was collected, concentrated and lyophilized. The compound was named as $O b D 1(100 \mathrm{mg})$ which was further characterized using spectroscopic techniques.

\section{Structure elucidation and Characterization of ObD1}

${ }^{1} \mathrm{H}$ and ${ }^{13} \mathrm{C}$ NMR spectra were recorded on Bruker NMR $500 \mathrm{MHz}$ instruments using $\mathrm{CDCl}_{3}$ as solvent. Chemical shift in ppm was measured relative to TMS as internal standard and coupling constant $J$, was measured in $\mathrm{Hz}$, multiplicity is indicated as: $\mathrm{s}=$ singlet, $\mathrm{d}=$ 
doublet, $\mathrm{t}=$ triplet, $\mathrm{m}=$ multiplets. The HRMS spectra were recorded on Bruker Micro Toff/ QII (Germany). IR spectra was recorded on FTIR Agilent machine.

\section{Antioxidant Activity}

\section{Superoxide anion radical scavenging assay}

Superoxide radical $\left(\mathrm{O}_{2}{ }^{--}\right)$, is a reactive radical which functions as a precursor of reactive oxygen species (ROS) and is mediator in oxidative chain reactions (Jing et al., 2015). The radical scavenging potential of different fractions was investigated based on a method suggested by Nishikimi et al., 1972. 0.06 M NBT and 0.156 M NADH were added to the various fraction concentrations $(25-400 \mu \mathrm{g} / \mathrm{ml})$, followed by the addition of $0.468 \mathrm{M}$ PMS. After the addition of PMS, the mixture was kept for 20 min. Finally, the yellow-colored NBT solution changed to blue colored solution and the absorbance was measured at $560 \mathrm{~nm}$.

Responses in terms of percentage inhibition obtained from NBT reduction depicted by color change were represented as:

$$
\text { Percent inhibition }=\frac{O D_{C}-O D_{S}}{O D_{C}} \times 100
$$

where ODC is the absorbance of control solution.

ODs is the absorbance of the sample solution.

\section{Lipid peroxidation assay}

The protocol proposed by Ohkawa et al., (1972) was followed for the evaluation of the lipid peroxidation inhibitory potential of $O$. bracteata. For this, $500 \mu$ l of lipid source $(10 \%$ homogenous egg), $1000 \mu \mathrm{l}$ of $150 \mathrm{mM} \mathrm{KCL}$ and $1000 \mu \mathrm{l}$ of different concentration of fractions $(25-400 \mu \mathrm{g} / \mathrm{ml})$ were mixed to make the reaction mixture. To continue lipo-oxidation, the above reaction mixture was dissolved in $100 \mu \mathrm{l}$ of $10 \mathrm{mM} \mathrm{FeCl}_{3}$ and kept for $30 \mathrm{~min}$ at $37{ }^{\circ} \mathrm{C}$. 
was heated at $95{ }^{\circ} \mathrm{C}$ for $1 \mathrm{~h}$, followed by cooling and centrifugation. Lastly, supernatant having pink color was collected and the absorbance was measured at $532 \mathrm{~nm}$.

The percent inhibition (anti-lipoperoxidation activity) was calculated by given formula below:

$$
\text { Percent inhibition }=\frac{O D_{C}-O D_{S}}{O D_{C}} \times 100
$$

where,

ODC is absorbance of control.

ODs is absorbance of sample mixture.

\section{Cell Culture}

IMR-32 (Human neuroblastoma), A-549 (Human alveolar basal epithelial), MG-63 (Human osteosarcoma) and HL-7702 (normal human hepatocyte) cell lines were purchased from the NCCS, Pune, India. Cells were cultured in DMEM with 10\% FBS and maintained with $\mathrm{CO}_{2}(5 \%)$ incubator at $37^{\circ} \mathrm{C}$. Media was changed with fresh media at regular intervals.

\section{MTT Assay}

The cytotoxic potential of isolated compound $O b D 1$ was evaluated via MTT assay based on the method prescribed by Liu et al., (2006). Suspensions of the various cell lines ( $8 \times$ $10^{3}$ cells $/ 0.1 \mathrm{ml}$ ) were seeded in 96 well microplates and incubated till confluency. Thereafter, cells were treated with $O b D 1$ using the serial dilution method. After 24 h, $20 \mu l$ of MTT was added into 96 well plate and incubated for $4 \mathrm{~h}$. The supernatant was discarded and $100 \mu \mathrm{l}$ DMSO was added to each well. Finally, absorbance was recorded at $570 \mathrm{~nm}$.

$$
\% \text { Growth inhibition }=\frac{O D_{C}-O D_{S}}{O D_{C}} \times 100
$$

where,

$$
\mathrm{OD}_{\mathrm{C}}=\text { untreated control; }
$$

ODs $=$ treated sample 


\section{Hoechst staining using Confocal Laser Scanning Microscopy (CLSM)}

The change in the nuclear morphology of cells was observed by Hoechst staining, as per the method suggested by Woo et al., (1972). The MG-63 cells $\left(2 \times 10^{5}\right.$ cells/well $)$ were cultured in six-well plates with $12 \mathrm{~mm}$ coverslips in each well. The cells were treated with GI50 $(37.53 \mu \mathrm{M})$ concentration of $O b D 1$ for $24 \mathrm{~h}$. Thereafter, cells were fixed using $4 \%$ paraformaldehyde and $2.5 \%$ glutaraldehyde solution for $30 \mathrm{~min}$ followed by the addition of Hoechst dye $(5 \mu \mathrm{g} / \mathrm{ml})$ for staining of cells. After $10 \mathrm{~min}$, cells were again washed with $1 \mathrm{x}$ PBS. Coverslips were mounted on the slides using Fluoromount. Nuclear morphological changes were observed under a Nikon eclipse Ti-2 fluorescence microscope (Nikon Corporation, Tokyo, Japan). were cultured for $24 \mathrm{~h}$ in a six-well plate followed by the $37.53 \mu \mathrm{M}$ concentration of DIBP. After $24 \mathrm{hr}$, DCFH-DA $(5 \mu \mathrm{M})$ was added to MG-63 cells and incubated for $30 \mathrm{~min}$ and a pellet was obtained using centrifugation. The pellet of cells was dissolved in 1x PBS (500 $\mu$ l). Finally, level of ROS generation was measured by a Flow cytometer. The results obtained were analyzed by using the software provided by BD Biosciences, USA (version 1.0.264.21).

\section{$\operatorname{MMP}(\Delta \Psi m)$ Analysis}

MG-63 cells were treated with DIBP $(37.53 \mu \mathrm{M})$ in six-well plate for $24 \mathrm{hr}$ and further analyzed using protocol recommended by Pajaniradje et al., (2010). Rhodamine-123 (10 $\mu \mathrm{g} / \mathrm{ml}$ ) was added to the cells and kept for $30 \mathrm{~min}$ in the dark. Finally, the cell-pellet was 
obtained and dissolved in $500 \mu \mathrm{l}$ of $1 \mathrm{x}$ PBS. The suspension of cells was analyzed by flow cytometry for determination of MMP.

\section{Cell-Cycle Phase Distribution Analysis}

BD Cycle test plus DNA Kit was used for the determination of the distribution of cellcycle phase in MG-63 cells. The MG-63 cells $\left(5 \times 10^{5}\right.$ cells/well) were cultured and treated with DIBP $(37.53 \mu \mathrm{M})$ for $24 \mathrm{~h}$. Further, cells were trypsinized and centrifugated for $5 \mathrm{~min}$ at 1500 rpm to obtain a pellet. Then, cells were fixed by using $70 \%$ ethanol solution followed by double-washing with 1x PBS. After fixation, the cell pellet was double-washed with 1x PBS followed by addition of $250 \mu \mathrm{l}$ of solution A and kept at room temperature (RT) for $10 \mathrm{~min}$ and then solution B $(200 \mu \mathrm{l})$ and solution C (200 $\mu \mathrm{l})$ were added. The cells were analyzed by flow cytometry to determine the cell cycle phase distribution using FlowJo software (version 10.7.1).

\section{Western Blotting}

The expression levels of proteins involved directly in the cell signaling pathway and apoptotic proteins (p-Akt, p53, caspase3- 9, and Bcl-xl and $\mathrm{p}-\mathrm{NF}-\mathrm{kB}$ ) were analyzed by $\mu \mathrm{M})$ for $24 \mathrm{hr}$. The cells were collected using a cell scraper and cell pellet was obtained by centrifugation at $1500 \mathrm{rpm}$ for $5 \mathrm{~min}$. For cell lysis, $150 \mu \mathrm{L}$ of RIPA buffer was added to the cell pellet and kept in ice for 25 min then centrifuged for $25 \mathrm{~min}$, supernatant was collected and protein concentration was quantified by Bradford method. Equal amount of protein $(40 \mu \mathrm{g})$ from DIBP treated and untreated cells was resolved by SDS-PAGE and was transferred to Polyvinylidene difluoride (PVDF) membrane using a wet transfer apparatus (Biorad, CA, US). 
$2 \mathrm{~h}$ at RT and incubated with antibodies p53 $(1: 1,000)$, caspase $3(1: 1,500)$, caspase $9(1: 1,500)$,

257

258

259

260

261

262

263

264

265

266

267

268

269

270

271

272

273

274

275

276

277

278

279

280

p-NFkB $(1: 2,000)$ and Bcl-xl (1:1,000). The membrane was washed thrice with TBST and HRP-conjugated secondary antibody $(1: 1,500)$ was added and the membrane was incubated for $2 \mathrm{~h}$ at room temperature. The blot was imaged under Image-Quant LAS 4000, GE Healthcare. Band densities were quantified with Alphaease FC Software (version 4.0). $\beta$-actin (1:500) as endogenous control was used for stabilizing the expression of the protein of interest.

\section{Quantitative Real-Time polymerase chain reaction (RT-qPCR)}

Total RNA was isolated with Trizol Reagent from the untreated and DIBP $(37.53 \mu \mathrm{M})$ treated MG-63 cells, as per manufacturer's protocol. The RNA samples were dissolved with TE buffer and incubated at $60^{\circ} \mathrm{C}$ for 5 min. DNA impurities were removed with DNase-I solution and the resulting solution was incubated for $30 \mathrm{~min}$ at $37^{\circ} \mathrm{C}$. Finally, quantification of RNA was performed using the Nano-Drop spectrophotometer (Thermo). Further, equal concentrations of RNAs were used for cDNA preparation using iScriptTM cDNA (Biorad) synthesis kit as per the manufacturer protocol. cDNA was used to perform RT-qPCR in a step one RT-qPCR system using iQ SYBR Supermix (Biorad). The genes used as the biomarkers for RT-qPCR analysis and their primer sequences (Table 1) were the following: p53, Bcl-2, CDK2, CyclinE and Caspase3. The expression of each gene was quantified by using threshold cycle method $2^{-\Delta \Delta \mathrm{Ct}} \pm \mathrm{SEM}$.

\section{Molecular Docking Studies}

PatchDock server, a geometry-based molecular docking algorithm, was used for docking analysis of ligand (DIBP) with CDK1 and p53 (Schneidman-Duhovny et al., 2005). The PDB files of ligand and CDK1 and p53 proteins were uploaded to PatchDock server for docking analysis, using cluster Root Mean Square Deviation (RMSD) at default value of 4.0 
and protein-small ligand complex type as the analysis parameters. The Residue Interaction

282

Networks (RIN) profile was obtained and representative structures of ligand and CDK/p53 complexes were generated using Residue Interaction Networks Generator (RING) 2.0 webserver (Piovesan et al., 2016). RIN analysis represents various interactions in the form of a detailed network model.

\section{Statistical Analysis}

One-way analysis of variance ANOVA was used to calculate statistical significance of all the values. The difference among the means was further compared by high-range statistical domain (HSD) using Tukey's test. For all the experiments, the values were represented as mean \pm standard errors in triplicate values. The probability $\mathrm{p} \leq 0.05$ was used to demonstrate that all the values were statistically significant at a $5 \%$ level.

\section{Results}

\section{Antioxidant Activity}

\section{Superoxide anion radical scavenging assay}

Among all the fractions of $O$. bracteata, the Obea showed effective radical-scavenging potential (Fig 1). As shown in Table 2, the $\mathrm{EC}_{50}$ values of Obea and rutin on scavenging superoxide radical were $95.12 \mu \mathrm{g} / \mathrm{ml}$ and $46.18 \mu \mathrm{g} / \mathrm{ml}$, respectively. At $400 \mu \mathrm{g} / \mathrm{ml}$, the percentage inhibition of the Obea was $85.36 \pm 2.60$ and that of rutin was $90.16 \pm 1.07$.

\section{Lipid peroxidation assay}

The Obea exhibited maximum potential to inhibit lipid peroxidation with lower EC50 value of $80.67 \mu \mathrm{g} / \mathrm{ml}$ as compared to $\mathrm{EC}_{50}$ value of $76.77 \mu \mathrm{g} / \mathrm{ml}$ of the reference compound, rutin (Table 3). The Obea has potent lipid inhibition percentage of $16.50 \pm 2.10$ at $25 \mu \mathrm{g} / \mathrm{ml}$ 
concentration whereas rutin has $20.06 \pm 1.36$ percentage inhibition. Therefore, keeping in mind their antioxidant potentials, Obea was further subjected to column chromatography.

Identification and isolation of bioactive compound

\section{Isolation of pure compound from silica gel chromatography}

ObD1 was isolated from $\mathrm{Ob} 4$ fraction of obea using silica gel chromatography and gave blue fluorescence on TLC plate when exposed to UV light (Plate I) (Fig 2). (DIBP). 


\section{Antiproliferative Activity ObD1}

In MG-63 cell line, $O b D 1$ has strong cytotoxic potential with GI50 value of $37.53 \mu \mathrm{M}$. The ObD1 also showed GI50 values of $56.05 \mu \mathrm{M}$ and $47.12 \mu \mathrm{M}$ against IMR-32 and A549, respectively (Table 4). Standard anticancer compound (Camptothecin) showed antiproliferative potential with GI50 value of $52.80 \mu \mathrm{M}$ against MG-63 cell line. ObD1 exhibited high antiproliferative activity in MG-63 cells as compared to IMR-32 and A549 (Fig 7), which was further explored for its apoptosis mechanism of action.

\section{Confocal Laser Scanning Microscopy (CLSM) Studies}

Hoechst 33342 is a DNA-specific fluorescent dye that penetrates the cell and intercalates at A-T regions of DNA (Kumar et al., 2015). CLMS studies showed significant differences among the DIBP treated and untreated MG-63 cells. Typical apoptosis signs such as the disintegration, shrinking, fragmented nuclei and chromatin condensation in MG-63 cells after the treatment with ObD1 $(37.53 \mu \mathrm{M})$, were seen in Fig 8. However, untreated cells showed non-apoptotic features, i.e., uniformly dispersed chromatin.

\section{Flow Cytometric Analysis}

\section{ROS Analysis}

ROS play a significant role in apoptosis and mitochondrial-mediated pathway (RedzaDutordoir and Averill-Bates, 2016). ROS generation was observed by DCFH-DA probe that is deacetylated by cell esterase enzyme and oxidized by ROS into the fluorescent $2^{\prime}, 7^{\prime}$ dichlorofluorescein (DCF) (Jia et al., 2020). The treatment of MG-63 cells with GI $_{50}$ (37.53 $\mu \mathrm{M})$ concentration of ObD1 resulted in an increase in the ROS generation by $78.6 \%$ as compared to untreated Mg-63 cells (37.4 \%) (Fig. 9A). MG-63 cells with ObD1 displayed an 
increase in the DCF fluorescence, which showed the generation of ROS as well as apoptosisinducing potential.

356

\section{Measurement of MMP (}

Mitochondria play a significant role in apoptosis pathways with apoptogenic factors like apoptosis-inducing factor, release of cytochrome c into cytoplasm and decrease in membrane potential ( $\Psi m$ ) (Wang and Youle, 2009). Rh-123 probe was used to detect MMP in MG-63 cells treated with $O b D 1(37.53 \mu \mathrm{M})$. These results showed that MG-63 cancer cells increased depolarization of mitochondrial membrane by $69.8 \%$ on exposure to $O b D 1$ in comparison to untreated cells (25.7\%) (Fig 9B).

\section{Cell Cycle Distribution}

MG-63 cells treated with $O b D 1(37.53 \mu \mathrm{M})$ showed significant cell-cycle delay at $\mathrm{G}_{0} / \mathrm{G}_{1}$ phase $(50.36 \pm 4.48 \%)$ as compared to the untreated cells $(25.3 \pm 1.84 \%)$, as shown in Fig 9C. The results showed that a dose-dependent effect with concomitant decrease in the S and $\mathrm{G}_{2} / \mathrm{M}$ phases.

\section{Western Blotting}

There was a decrease in the expression of p-AKT, Bcl-xl and p-NF- $\kappa \mathrm{B}$ in MG-63 cells treated with $O b D 1(37.53 \mu \mathrm{M})$, but the expression of Caspase 3, Caspase 9 and p53 was upregulated in comparison to the untreated control cells. (Fig 10).

\section{RT-qPCR Analysis}

The RT-qPCR analysis of MG-63 cells with ObD1 $(37.53 \mu \mathrm{M})$ displayed an enhancement of 5.43-fold and 7.51-fold in p53 and caspase-3 expression, respectively, whereas 
decrease of 0.51-fold, 0.37-fold and 0.69-fold in Bcl-2, CDK2 and Cyclin E, respectively, as compared to untreated MG-63 cells, as shown in Fig 11.

\section{Molecular Docking}

Material PatchDock server was used for docking analysis of ligand with CDK1 and p53. We observed the docking energy for ligand-CDK-1 and ligand-p53 complex to be -133.96 $\mathrm{kJ} / \mathrm{mol}$ and -151.13, respectively, that indicated the stability of the docked complex (Fig.12).

To identify key residues involved in the interactions, the residue interaction network (RIN) profiles of docked complex was generated using RING 2.0 web server. Analysis of docked structure and RIN plot showed that Leu 67, Phe 82, Gly 16, Ala 31, Gly 11, Phe 80, Asp 145, Ala 144, Asn 132, Gln 131 and Asp 127 amino acids were predicted CDK residues which are involved in binding with DIBP in complex structure. Similarly, we observed that Ple 232, His 233, Glu 221, Val 225, Glu 224, Gly 199, Pro 219, Thr 231, Pro 223, Asn 200, and Val 218 were predicted p53 residues for interaction with DIBP in docked complex. (Fig. 12D).

\section{Discussion}

Secondary plant metabolites play a crucial role in chemoprevention strategies. Numerous natural compounds have shown the potential of altering the cellular signaling pathways due to their antioxidant, anti-metastatic, pro-apoptotic and anti-proliferative properties (Gali-Muhtasib et al., 2015; Shi et al., 2018). These natural compounds specifically halt the progress of carcinogenesis by repairing DNA damage and reducing inflammation (Costea et al., 2019; Kopustinskiene et al., 2020). DIBP effectively control the proliferation of MG-63 cells with a concentration of $37.53 \mu \mathrm{M}$ (GI50). Khatiwora et al. (2013) reported a bioactive secondary metabolite - Dibutyl Phthalate isolated from ethyl acetate extract of Ipomoea carnea which showed antibacterial activity against Klebseilla pneumonia, Proteus 
mirabilis and Pseudomonas aeruginosa. Maskovic and co-workers (2015) reported that water

405

406

407

408

409

410

411

412

413

414

415

416

417

418

419

420

421

422

423

424

425

426

427

428 extract of Onosma aucheriana has effective cytotoxic potential with GI 50 values of 50.57, 40.34 and $25.24 \mu \mathrm{g} / \mathrm{ml}$ in $\mathrm{RD}$ (human rhabdomyosarcoma), Hep2c (human cervix carcinoma) and L2OB (murine fibroblast) cell lines, respectively. Natural compounds with antioxidant properties upsurge oxidative stress in cancer cells disabling various pro-survival signals including ROS-scavenging mechanism, and signaling pathways suppressing cancer cell growth (Carneiro and El-Deiry, 2020). DIBP treatment induced nuclear condensation and nuclear fragmentation in MG-63 cells which is a sign of apoptosis. Kundakovic et al. (2006) demonstrated Onosma arenaria to possess potent cytotoxicity against human cervix adenocarcinoma cells (HeLa) and leukaemia K562 cells. Ukwubile et al. (2020) reported dibutyl phthalate isolated from ethyl acetate extract of Melastomastrum capitatum to show cytotoxic potential against breast cancer cell line (MCF-7) and ovarian cancer cell line (OV-7) with $\mathrm{IC}_{50}$ values of $22.71 \mu \mathrm{g} / \mathrm{ml}$ and $24.13 \mu \mathrm{g} / \mathrm{ml}$, respectively. The production of reactive oxygen species (ROS) and disruption of mitochondrial membrane potential play a key role in the induction of apoptosis via activation of caspase pathway (Simon et al., 2000). DIBP from O. bracteata exhibited $78.6 \%$ increase in intracellular ROS production, as evident from flow cytometer studies. Abnormal ROS generation is identified as a strong mediator of inflammation and consequential cell injury leading to apoptosis (Kehrer Klotz. 2015). ROS generation activates apoptosis by triggering the mitochondrial-dependent apoptotic pathway, mitogenactivated protein kinase (MAPK) pathway and induces proapoptotic signals resulting in cell death (Li ZY et al., 2011). Thus, ROS act as key signaling messengers in determining apoptosis or cell survival. Dilshara and co-authors (2018) reported the subsequent inhibition of growth of colon cancer (HCT 116) cells at sub-G1 phase with treatment of $\beta$-hydroxyisovaleryl shikonin isolated from roots of Lithospermum erythrorhizon Siebold \& Zucc., (Boraginaceae) via triggering ROS production and promoting the apoptosis by activating capase8/9. The DIBP 
successfully reduced the MMP $(\Delta \Psi \mathrm{m})$ by $69.68 \%$ at the $\mathrm{GI}_{50}$ concentration and delayed the growth of MG-63 cancer cells at the $\mathrm{G}_{0} / \mathrm{G}_{1}$ phase by $50.36 \%$. Chan and coworkers (2017) reported that triptolide (natural compound) has the potential to arrest the Murine Leukemia Cells (WEHI-3) cells at $\mathrm{G}_{0} / \mathrm{G}_{1}$ phase via production of $\mathrm{Ca}^{2+}$, ROS generation and reduction in mitochondria membrane potential that eventually led to apoptosis. Kumar et al. (2020) reported that ethanolic extract of Onosma bracteata has hepatoprotective potential against hepatic damage induced by carbon tetra chloride $\left(\mathrm{CCl}_{4}\right)$ in male Wistar rats due to the presence of phytoconstituents in it. Kaur et al. (2020) reported that Epiafzelechin isolated from ethyl acetate fraction of Cassia fistula showed antiproliferative activity due to increased ROS generation, decreased in MMP and $\mathrm{G}_{0} / \mathrm{G}_{1}$ phase arrest.

Dysfunction of proto-oncogenes and tumor suppressor genes is one of the pathogenic factors for osteosarcoma (OS). Like most other malignancies, OS involves multiple oncogenes activations and tumor suppressor gene mutations, including proto-oncogene c-myc, ras, fos, etc., and tumor suppressor gene p53, etc (Xia et al., 2015). DIBP compound upregulated the activity of mutant p53 to induce apoptosis in MG-63 cells because the accumulation of p53 promotes apoptosis induction in cancer cells. Preventing mutant p53 oncogenic potential can be an effective approach to treat human cancers as it can control many cellular functions including cell cycle arrest, apoptosis and senescence (Blandino and Di Agostino. 2018; Cheng et al., 2020). In the present study, DIBP significantly upregulated the level of p53, caspase3 and caspase9 and downregulated the expression of p-Akt, p-NF- $\mathrm{kB}$ and Bcl-xl as indicated in western blot studies. DIBP treatment $(37.53 \mu \mathrm{M})$ downregulated the expression of the Bcl-xl showing the sign of apoptosis in osteosarcoma MG-63 cells. DIBP increased the gene expression levels of caspase $3, \mathrm{Bcl}-2$ and p53 but decreased the expression of CDK2 and Cyclin

452 E as detected in RT-qPCR studies. NFкB which is generally over-expressed in different type 453 of cancers and is responsible for transcription of several genes involved in tumor cell 
proliferation, inflammation and metastasis (Yan et al., 2010). Stress signals stimulate the release of cytochrome c from mitochondria which then associates with $47 \mathrm{kDa}$ procaspase9/Apaf-1 oligomer. This binding of procaspase-9 to apaf-1 initiates processing and activation of procaspase-9 resulting in cleavage at Asp315 and Asp330 producing p35 and p37 subunits which amplify the apoptotic response. Cleaved caspase-9 further activates caspase- 3 resulting in apoptosis (Noori et al., 2021). Bands corresponding to $35 \mathrm{kDa}$ confirmed our findings. Jannus et al., 2020, reported that diamine-PEGylated Oleanolic Acid (OADP) showed strong anti-cancer effects in Human Hepatoma Cells (HepG2) causing cell cycle arrest in the $\mathrm{G}_{0} / \mathrm{G}_{1}$ phase and the loss of the mitochondrial membrane potential (MMP). Apoptosis induction ability of OADP was related to the upregulated expression of caspase-8, caspase-9, caspase-3, Bak, p21 and p53 and downregulated expression of Bcl-2. Cheng et al. (2020) reported that mulberry water extract had cytotoxic ability against human liver cancer cell line (HepG2) and human hepatocellular carcinoma cell line (Hep3B) via activation of caspase-3, -9, -8 and downregulation in Bcl-2 via apoptotic mediated pathways. Molecular docking studies also indicate that DIBP stably binds to p53 $(-151.13 \mathrm{~kJ} / \mathrm{mol})$ and CDK1 $(-133.96 \mathrm{~kJ} / \mathrm{mol})$. These results recommend that DIBP is an effective molecule with potent antiproliferative activity via apoptosis-inducing mechanisms, viz. disruption of $\Delta \Psi \mathrm{m}$, cell cycle delayed at $\mathrm{G}_{0} / \mathrm{G}_{1}$ with downregulation of Cyclin E and CDK2, increase in the expression levels of p53, caspase-3 and caspase-9 and decrease in the expression of Bcl-xL, p-NFkB, Bcl-2 and p-Akt (Fig.13).

\section{Conclusion}

DIBP exhibited strong cytotoxic property in MG-63 cell line (osteosarcoma) and induced apoptosis via Akt/p53-cyclin pathways. DIBP increased ROS, decreased MMP and delayed the cell cycle at $\mathrm{G}_{0} / \mathrm{G}_{1}$ phase. It decreased the expression of $\mathrm{p}-\mathrm{NF}-\kappa \mathrm{B}, \mathrm{Bcl}-2$, $\mathrm{p}-\mathrm{Akt}$, CDK2, cyclin E and upregulated anti-apoptotic protein (Bcl-xl), Caspase 3-9 and p53 genes. 
479 This is the first report which unveils the cytotoxic potential of DIBP obtained from O. bracteata

480

481

482

483

484

485

486

487

488

489

490

491

492

493

494

495

496

497

498

499

500

501

502

503

504 against osteosarcoma cell line (MG-63). The results showed that the compound DIBP has a unique ability to target the aberrant signaling pathways of MG-63 cells leading to apoptosis.

\section{Declarations}

Compliance with ethical standards: This manuscript is original, has not been published before and is not currently being considered for publication elsewhere. Accepted principles of ethical and professional conduct have been followed while executing this research work. NO experiment was carried out on humans or animals to accomplish this research work.

Conflicts of Interest: No potential conflict of interest was reported by all author(s).

Consent to participate: No human participants were required/used to carry out the reported research work. As there are no participants, so consent to participate is not required.

Consent to publish: We the undersigned declare that this manuscript is original, has not been published before and is not currently being considered for publication elsewhere. We confirm that the manuscript has been read and approved by all named authors and that there are no other persons who satisfied the criteria for authorship but are not listed. We further confirm that the order of authors listed in the manuscript has been approved by all of us. We understand that the Corresponding Author is the sole contact for the Editorial process. He/she is responsible for communicating with the other authors about progress, submissions of revisions and final approval of proofs.

\section{Author Contributions:}

$\mathrm{AK}$ and SJK designed the research. AK, SD, ST and SJK performed the experiments and analyzed data. AK and SD isolated the compounds. AK, SD performed NMR experiments. AK, SD, PPS, US and SK2 collected NMR data, solved and refined the structures. AK and ST performed RT-qPCR analysis. AK, SK1, SD and SJK wrote the manuscript. All authors have read and agreed to the published version of the manuscript. 


\section{Acknowledgment}

The authors are thankful to the University Grants Commission (UGC)- Basic Scientific Research (BSR), DST-PURSE, DST-FIST programme for providing financial assistance. We also like to acknowledge UGC, New Delhi for the instrumentation facility provided under UGC-DRS V, RUSA 2.0 scheme, CPEPA and UPE program and Centre of Emerging Life Sciences, Guru Nanak Dev University, Amritsar (India) for providing the required support and facilities. The authors are also thankful to the Director, CSIR-IHBT, Palampur.

Availability of data and materials: The raw data supporting the conclusions of this article will be made available by the authors, without undue reservation, to any qualified researcher.

\section{Competing interests}

The authors declare that they have no known competing financial interests or personal relationships that could have appeared to influence the work reported in this paper

\section{Reference}

- Albaqami J, Myles LE, Tiriveedhi V (2018) The Effect of Onosma bracteatum in cancer cells. MOJ Bioequiv 5:321-325. doi: 10.15406/mojbb.2018.05.00122.

- Bao J, Zeng J, Song C, Yu H, Shi Q, Mai W, Qu G (2019) A Retrospective Clinicopathological Study of Osteosarcoma Patients with Metachronous Metastatic Relapse. Journal of Cancer 10:2982-2990. doi:10.7150/jca.30750.

- Bielack S, Carrle D, Casali PG, ESMO Guidelines Working Group (2009) Osteosarcoma: ESMO clinical recommendations for diagnosis, treatment and follow-up. Annals of Oncology, 20:137-139. doi: 10.1093/annonc/mdp154.

- Blandino G, Di Agostino S (2018) New therapeutic strategies to treat human cancers expressing mutant p53 proteins. Journal of Experimental \& Clinical Cancer Research 37:1-13. doi: /10.1186/s13046-018-0705-7.

- Carneiro BA, El-Deiry WS (2020) Targeting apoptosis in cancer therapy. Nature Reviews Clinical Oncology 17:395-417. doi: 10.1038/s41571-020-0341-y.

- Chan SF, Chen YY, Lin JJ, Liao CL, Ko YC, Tang NY, Kuo CL, Liu KC, Chung JG (2017) Triptolide induced cell death through apoptosis and autophagy in murine 
leukemia WEHI-3 cells in vitro and promoting immune responses in WEHI-3 generated leukemia mice in vivo. Environmental toxicology 32:550-568. doi: 10.1002/tox.22259.

- Chen Y, Li H, Zhang W, Qi W, Lu C, Huang H, Yang Z, Liu B, Zhang L (2020) Sesamin suppresses NSCLC cell proliferation and induces apoptosis via Akt/p53 pathway. Toxicology and Applied Pharmacology 387:1-11. doi: 10.1016/j.taap.2019.114848.

- Cheng KC, Wang CJ, Chang YC, Hung TW, Lai CJ, Kuo CW, Huang HP (2020) Mulberry fruits extracts induce apoptosis and autophagy of liver cancer cell and prevent hepatocarcinogenesis in vivo. Journal of Food and Drug Analysis 28:84-93. doi: 10.1016/j.jfda.2019.06.002

- Choudhari AS, Mandave PC, Deshpande M, Ranjekar P, Prakash O (2020) Phytochemicals in cancer treatment: From preclinical studies to clinical practice. Frontiers in pharmacology 10:1-17. doi: 10.3389/fphar.2019.01614.

- Corre I, Verrecchia F, Crenn V, Redini F, Trichet V (2020) The Osteosarcoma Microenvironment: A Complex but Targetable Ecosystem. Cells 9:1-25. doi:10.3390/cells9040976.

- Costea T, Nagy P, Ganea C, Szöllősi J, Mocanu MM (2019) Molecular mechanisms and bioavailability of polyphenols in prostate cancer. International journal of molecular sciences 20:1-39. doi: 10.3390/ijms20051062.

- Deeb D, Gao X, Jiang H, Janic B, Arbab AS, Rojanasakul Y, Dulchavsky SA, Gautam SC (2010) Oleanane triterpenoid CDDO-Me inhibits growth and induces apoptosis in prostate cancer cells through a ROS-dependent mechanism. Biochemical pharmacology 79:350-360. doi: 10.1016/j.bcp.2009.09.006.

- Dilshara MG, Karunarathne WAHM, Molagoda IMN, Kang CH, Jeong JW, Choi YH, Kim GY (2018) $\beta$-Hydroxyisovalerylshikonin promotes reactive oxygen species production in HCT116 colon cancer cells, leading to caspase-mediated apoptosis. Revista Brasileira de Farmacognosia 28:344-351. doi: 10.1016/j.bjp.2018.03.003.

- Durfee RA, Mohammed, M, Luu, HH (2016) Review of osteosarcoma and current management. Rheumatology and therapy 3:221-243. doi: 10.1007/s40744-0160046-y. 
- Elias A, Shebaby WN, Nehme B, Faour W, Bassil BS, El Hakim J, Iskandar R, DibJalbout N, Mroueh M, Daher C, Taleb RI (2019). In Vitro and In Vivo Evaluation of the Anticancer and Anti-inflammatory Activities of 2-Himachelen-7-ol isolated from Cedrus libani. Scientific reports, 9:1-9. doi: 10.1038/s41598-019-49374-9.

- Farooq U, Pan Y, Disasa D, Qi J (2019) Novel Anti-Aging Benzoquinone Derivatives from Onosma bracteatum Wall. Molecules 24:1-9. doi: 10.3390/ molecules24071428.

- Gali-Muhtasib H, Hmadi R, Kareh M, Tohme R, Darwiche N (2015) Cell death mechanisms of plant-derived anticancer drugs: beyond apoptosis. Apoptosis 20: 1531-1562. doi: 10.1007/s10495-015-1169-2.

- Garg B, Bisht T, Ling YC (2014) Sulfonated graphene as highly efficient and reusable acid carbocatalyst for the synthesis of ester plasticizers. RSC Adv 4:5729757307. doi: 10.1039/c4ra11205a.

- Huang CY, Ju DT, Chang C F, Reddy PM, and Velmurugan BK (2017) A review on the effects of current chemotherapy drugs and natural agents in treating nonsmall cell lung cancer. Biomedicine 7:12-23. doi: 10.1051/bmden/2017070423.

- Jannus F, Medina-O’Donnell M, Rivas F, Díaz-Ruiz L, Rufino-Palomares EE, Lupiáñez JA, Parra A, Reyes-Zurita, FJ (2020). A Diamine-PEGylated Oleanolic Acid Derivative Induced Efficient Apoptosis through a Death Receptor and Mitochondrial Apoptotic Pathway in HepG2 Human Hepatoma Cells. Biomolecules, 10:1375. doi: 10.3390/biom10101375.

- Jia P, Dai C, Cao P, Sun D, Ouyang R, Miao Y (2020) The role of reactive oxygen species in tumor treatment. RSC Advances 10:7740-7750. doi: 10.1039/C9RA10539E.

- Jing L, Ma H, Fan P, Gao, R, Jia Z (2015). Antioxidant potential, total phenolic and total flavonoid contents of Rhododendron anthopogonoides and its protective effect on hypoxia-induced injury in PC12 cells. BMC complementary and alternative medicine 15:1-12. doi: 10.1186/s12906-015-0820-3.

- Joselin AP, Schulze-Osthoff K, Schwerk C (2006) Loss of Acinus inhibits oligonucleosomal DNA fragmentation but not chromatin condensation during apoptosis. Journal of Biological Chemistry 281:12475-12484. doi: 10.1074/jbc.m509859200. 
- Kaur S, Kumar A, Thakur S, Kumar K, Sharma R, Sharma A, Singh P, Sharma U, Kumar S, Landi M, Brestič, M, Kaur S (2020) Antioxidant, Antiproliferative and Apoptosis-Inducing Efficacy of Fractions from Cassia fistula L. Leaves. Antioxidants 9:1-31. doi:10.3390/antiox9020173.

- Kazemi M (2013) Essential oil composition of Anchusa italica from Iran. Chemistry of Natural Compounds 49:369-370. doi: 10.1007/s10600-013-0611-3.

- Kehrer JP, Klotz LO (2015) Free radicals and related reactive species as mediators of tissue injury and disease: implications for health. Critical reviews in toxicology 45:765-798. doi: 10.3109/10408444.2015.1074159.

- Khatiwora E, Adsula VB, Kulkarni M, Deshpande NR, Kashalkar RV (2013) Isolation and characterization of substituted dibutyl phthalate from Ipomoea carnea stem. Der Pharma Chemica 5:5-10.

- Kim YS, Hwang JW, Sung SH, Jeon YJ, Jeong JH, Jeon BT, MoonSH, Park PJ (2015). Antioxidant activity and protective effect of extract of Celosia cristata L. flower on tert-butyl hydroperoxide-induced oxidative hepatotoxicity. Food chemistry 168:572-579. doi: 10.1016/j.foodchem.2014.07.106.

- Kopustinskiene DM, Jakstas V, Savickas A, Bernatoniene J (2020) Flavonoids as anticancer agents. Nutrients 12:1-26. doi: 10.3390/nu12020457.

- Kumar A, Kaur S, Pandit K, Kaur V, Thakur S and Kaur S (2020) Onosma bracteata Wall. induces $\mathrm{G}_{0} / \mathrm{G}_{1}$ arrest and apoptosis in MG-63 human osteosarcoma cells via ROS generation and AKT/GSK3ß/cyclin E pathway. Environmental Science and Pollution Research 1-22. doi: 10.1007/s11356-020-11466-9.

- Kumar A, Kaur V, Pandit K, Tuli HS, Sak K, Jain SK, Kaur S (2020) Antioxidant Phytoconstituents From Onosma bracteata Wall. (Boraginaceae) Ameliorate the CCl4 Induced Hepatic Damage: In Vivo Study in Male Wistar Rats. Frontiers in pharmacology 11:1-18. doi: 10.3389/fphar.2020.01301.

- Kumar N, Kumar R and Kishore K (2013) Onosma L.: A review of phytochemistry and ethnopharmacology. Pharmacognosy Rev. 7:140. doi: 10.4103/09737847.120513.

- Kumar, M., Kaur, P., Kumar, S., \& Kaur, S. (2015). Antiproliferative and apoptosis inducing effects of non-polar fractions from Lawsonia inermis L. in cervical (HeLa) cancer cells. Physiology and Molecular Biology of Plants 21:249-260. doi: 10.1007/s12298-015-0285-3. 
- Kundakovic T, Stanojković T, Juranić Z, Kovačević N (2006) Cytotoxicity in vitro of naphthazarin derivatives from Onosma arenaria. Phytotherapy Research 20:602-604. doi: 10.1002/ptr.1899.

- $\quad$ Li SW, Hu KZ, Chen SC, Liu SL, Wang YH (2018) High expression of long noncoding RNA LOC730101 correlates with distant metastasis and exhibits a poor prognosis in patients with osteosarcoma. Eur Rev Med Pharmacol Sci 22:41154120. doi: 10.26355/eurrev_201807_15403.

- Li ZY, Yang Y, Ming M, Liu B (2011) Mitochondrial ROS generation for regulation of autophagic pathways in cancer. Biochem. Biophys. Res. Commun 414: 5-8. doi: 10.1016/j.bbrc.2011.09.046.

- Lin SR, Chang CH, Hsu CF, Tsai MJ, Cheng H, Leong MK, Sung PJ, Chen JC, Weng CF (2020) Natural compounds as potential adjuvants to cancer therapy: Preclinical evidence. British journal of pharmacology 177:1409-1423. doi: 10.1111/bph.14816.

- Liu J, Li Y, Ren W, Hu WX (2006) Apoptosis of HL-60 cells induced by extracts from Narcissus tazetta var. chinensis. Cancer letters 242:133-140. doi: 10.1016/j.canlet.2005.11.023.

- Loeb KR, Loeb, LA (2000) Significance of multiple mutations in cancer. Carcinogenesis 21: 379-385. doi: 10.1093/carcin/21.3.379.

- Maskovic PZ, Diamanto LD, Vujic JM, Cvetanović AD, Radojković MM, Gadžurić SB,Zengin G (2015) Onosma aucheriana: A source of biologically active molecules for novel food ingredients and pharmaceuticals. Journal of functional foods 19:479-486. doi: 10.1016/j.jff.2015.09.054.

- Milkovic L, Zarkovic, N, Saso L (2017) Controversy about pharmacological modulation of $\mathrm{Nrf} 2$ for cancer therapy. Redox biology 12:727-732. doi: 10.1016/j.redox.2017.04.013.

- Misaghi A, Goldin A, Awad M, Kulidjian AA (2018) Osteosarcoma: a comprehensive review. Sicot-j, 12:1-8. doi: 10.1051/sicotj/2017028.

- Nishikimi M, Rao NA and Yagi K (1972) The occurrence of superoxide anion in the reaction of reduced phenazine methosulfate and molecular oxygen. Biochemical and biophysical research communications 46:849-854. doi: 10.1016/S0006291X(72)80218-3. 
- Noori AR, Tashakor A, Nikkhah, M, Eriksson LA, Hosseinkhani S, Fearnhead HO (2021) Loss of WD2 subdomain of Apaf-1 forms an apoptosome structure which blocks activation of caspase-3 and caspase-9. Biochimie, 180:23-29. doi: 10.1016/j.biochi.2020.10.013.

- Ohkawa H, Ohishi N, Yagi K (1979) Assay for lipid peroxides in animal tissues by thiobarbituric acid reaction. Analytical biochemistry 95:351-358. doi: 10.1016/0003-2697(79)90738-3.

- Pajaniradje S, Mohankumar K, Pamidimukkala R, Subramanian S, Rajagopalan R, (2014) Antiproliferative and apoptotic effects of Sesbania grandiflora leaves in human cancer cells. BioMed research international 1:1-11. doi:10.1155/2014/474953.

- Piovesan D, Minervini G, Tosatto SC (2016) The RING 2.0 web server for high quality residue interaction networks. Nucleic acids research 44:367-374. doi: 10.1093/nar/gkw315.

- Redza-Dutordoir M, Averill-Bates DA (2016) Activation of apoptosis signalling pathways by reactive oxygen species. Biochimica et Biophysica Acta (BBA)Molecular Cell Research 1863:2977-2992. doi: 10.1016/j.bbamcr.2016.09.012.

- Saraste A, Pulkki K (2000) Morphologic and biochemical hallmarks of apoptosis. Cardiovascular research 45:528-537. doi: 10.1016/S00086363(99)00384-3.

- Schneidman-Duhovny D, Inbar Y, Nussinov R, Wolfson HJ (2005) PatchDock and SymmDock: servers for rigid and symmetric docking. Nucleic acids research 33: 363-367. doi: 10.1093/nar/gki481.

- Shi L, Qin H, Jin X, Yang X, Lu X, Wang H, Wang R, Yu D, Feng, B (2018) The natural phenolic peperobtusin A induces apoptosis of lymphoma U937 cells via the Caspase dependent and p38 MAPK signaling pathways. Biomedicine \& Pharmacotherapy 102:772-781. doi: 10.1016/j.biopha.2018.03.141.

- Siamof CM, Goel S, Cai W (2020) Moving beyond the pillars of cancer treatment: perspectives from nanotechnology. Frontiers in Chemistry, 8:1088. doi: 10.3389/fchem.2020.598100.

- Simon HU, Haj-Yehia A, Levi-Schaffer F (2000) Role of reactive oxygen species (ROS) in apoptosis induction. Apoptosis, 5:415-418. doi: 10.1023/A:1009616228304. 
- $\quad$ Sun LR, Zhou W, Zhang HM, Guo QS, Yang W, Li BJ, Sun ZH, Gao SH, Cui RJ (2019) Modulation of multiple signaling pathways of the plant-derived natural products in cancer. Frontiers in Oncology, 9:1-15. doi: 10.3389/fonc.2019.01153.

- Ukwubile CA, Ikpefan EO, Malgwi TS, Bababe AB, Odugu JA, Angyu AN, Otalu O, Bingari MS and Nettey HI (2020) Cytotoxic effects of new bioactive compounds isolated from a Nigerian anticancer plant Melastomastrum capitatum Fern. leaf extract. Scientific African 8:1-9. doi: 10.1016/j.sciaf.2020.e00421.

- Ved DK, Sureshchandra ST, Barve V, Srinivas V, Sangeetha, S, Ravikumar K, et al. (2016). (envis. frlht. org/frlhtenvis. nic. in). (Bengaluru: FRLHT's ENVIS Centre on Medicinal Plants), 1475-1484.

- Wang C, Youle RJ (2009) The role of mitochondria in apoptosis. Annual review of genetics 43:95-118. doi: 10.5483/bmbrep.2008.41.1.011.

- Wang JP, Hsieh CH, Liu CY, Lin KH, Wu PT, Chen KM and Fang K (2017) Reactive oxygen species-driven mitochondrial injury induces apoptosis by teroxirone in human non-small cell lung cancer cells. Oncology Letters 14, 35033509. doi: 10.3892/ol.2017.6586.

Web link: https://www.derpharmachemica.com/pharma-chemica/isolation-andcharacterization-of-substituted-dibutyl-phthalate-from-ipomoea-carnea-stem.pdf.

- Woo M, Hakem R, Soengas MS, Duncan GS, Shahinian A, Kägi D, Hakem A, McCurrach M, Khoo W, Kaufman SA, Senaldi G (1998) Essential contribution of caspase 3/CPP32 to apoptosis and its associated nuclear changes. Genes \& development 12:806-819. doi: 10.1101/gad.12.6.806.

- Xia P, Sun Y, Zheng C, Hou T, Kang M, Yang X. (2015) p53 mediated apoptosis in osteosarcoma MG-63 cells by inhibition of FANCD2 gene expression. International journal of clinical and experimental medicine, 8:11101. ISSN:19405901/IJCEM0010324.

- Yan M, Xu Q, Zhang P, Zhou X, Zhang Z, Chen W (2010). Correlation of NFkappa B signal pathway with tumor metastasis of human head and neck squamous cell carcinoma. BMC Cancer, 10:437-441. doi: 10.1186/1471-2407-10-437.

- Zeb MA, Sajid M, Rahman TU, Khattak KF, Ullah S, Pandey S, Salahuddin M, Begum Z (2015) Phytochemical Screening and Antibacterial Activity of Opuntia dillenii and Onosma bracteatum. J Microbiol Exp 3:216-219. doi: 10.15406/jmen.2015.02.00074. 


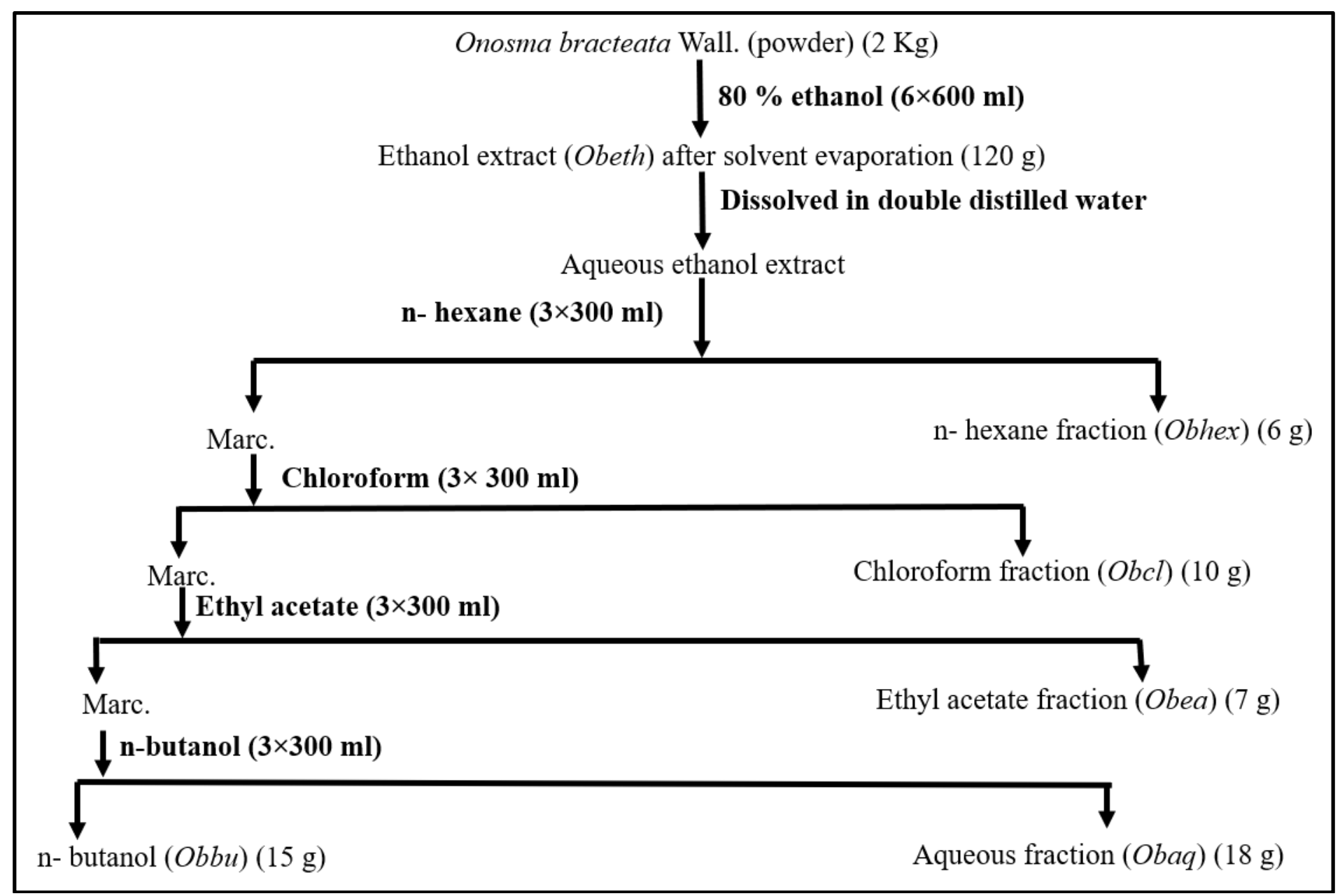

Flow chart 1: Schematic representation of extraction from $O$. bracteata using maceration method. 


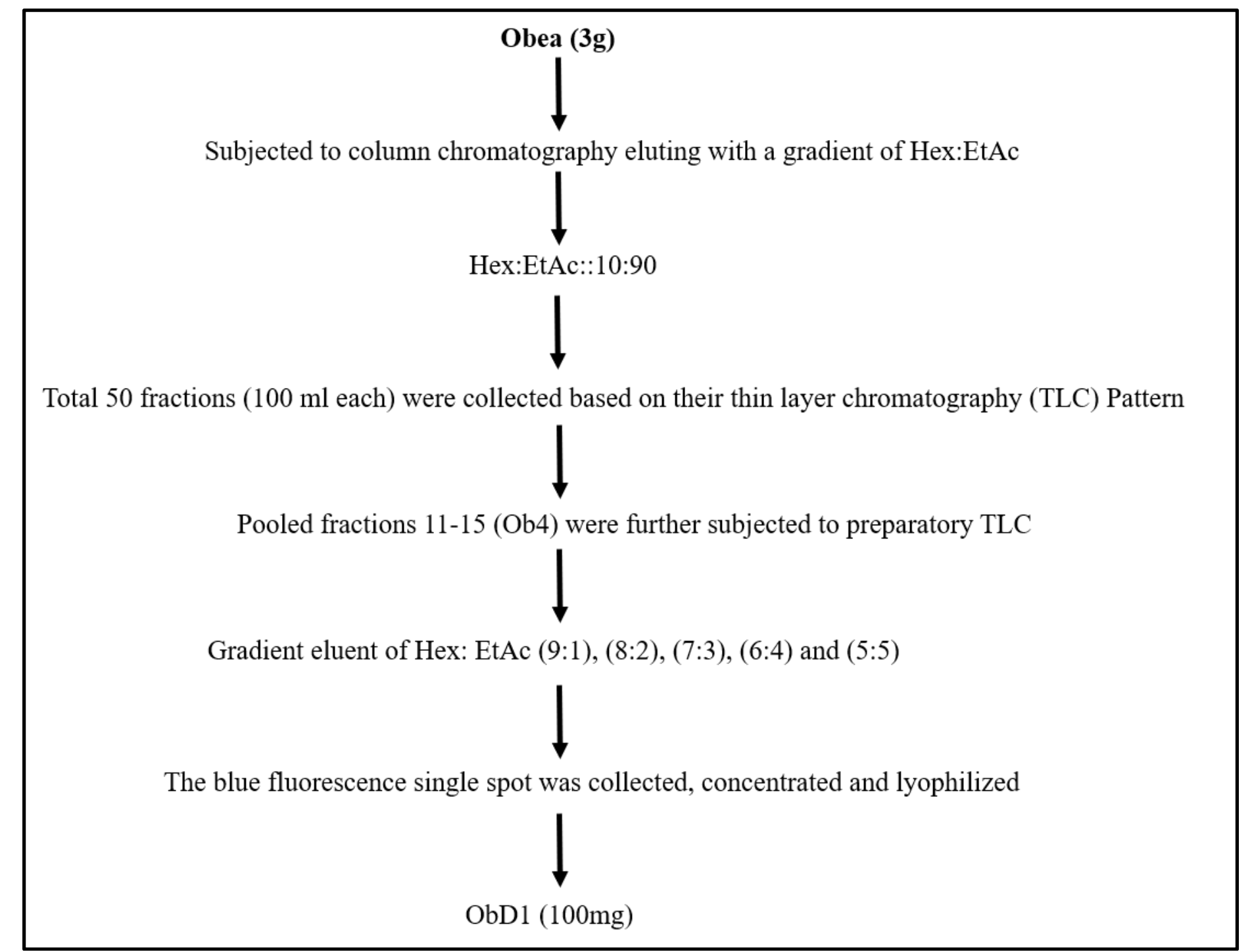

Flow chart 2: Schematic representation of $O b D 1$ isolation from $O$. bracteata using coloumn chromatography. 


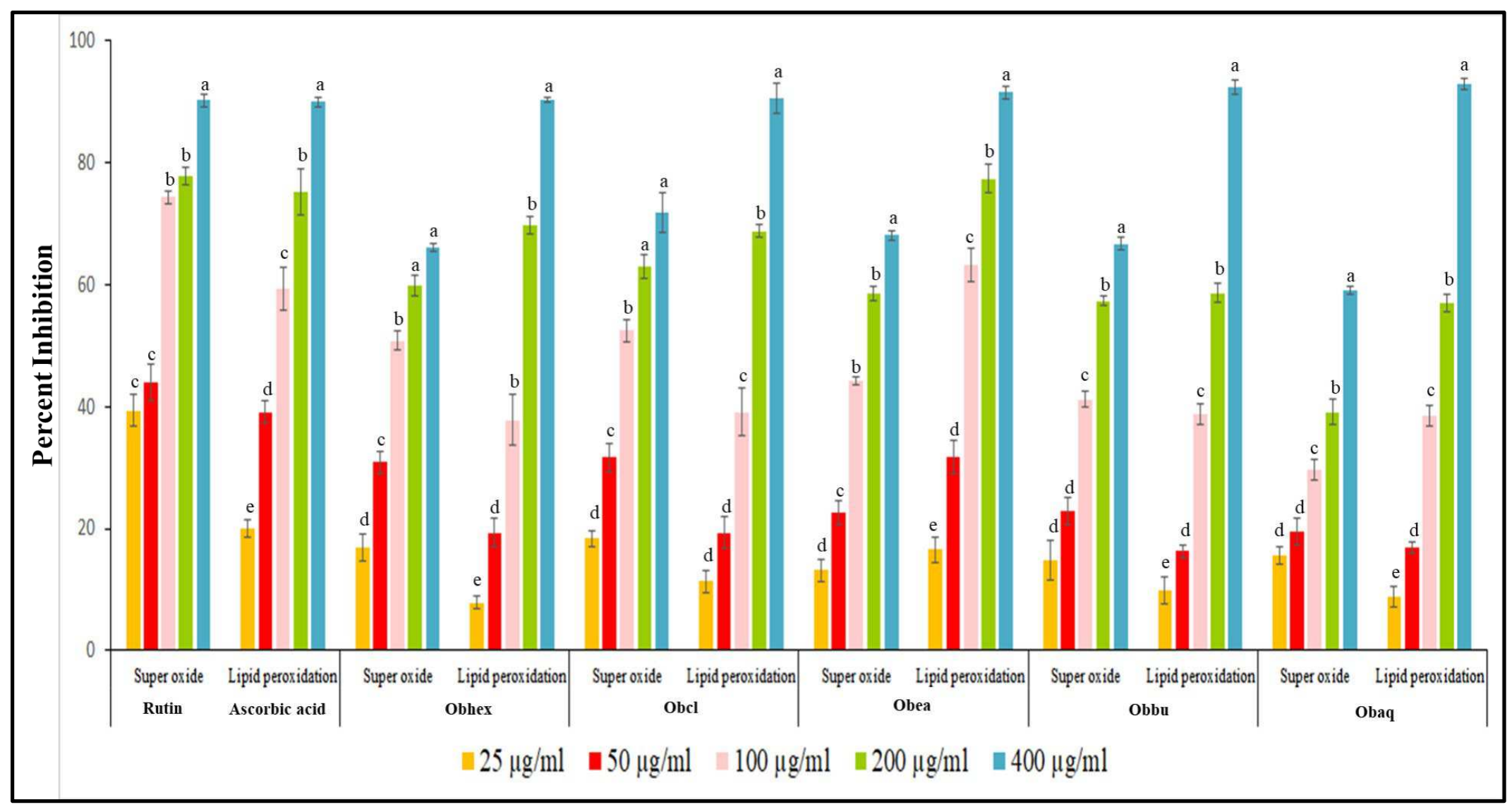

Figure. 1. Antioxidant potential of various fractions obtained from $O$. bracteata using Superoxide anion radical scavenging assay and lipid peroxidation assay. Result showed mean $\pm \mathrm{SE}$ of performed three experiments independent in triplicates. Data labels with different letters represent significant difference among them at $(\mathrm{p} \leq 0.05)$. 


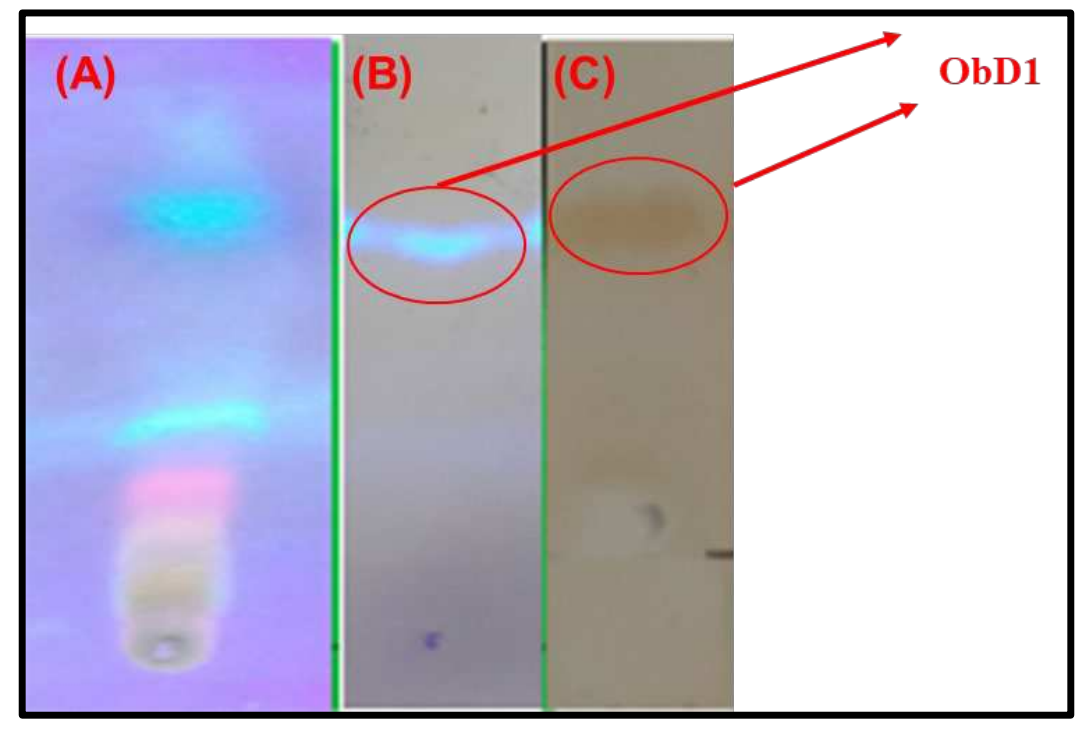

Figure 2. Thin layer chromatography of Obea fraction (A) of O. bracteata, (B) compound ObD1 after column chromatography under $365 \mathrm{~nm}$ light, $(C)$ ObD1 after exposure of iodine ((Solvent system- n-hexane: ethyl acetate (7:3)). 


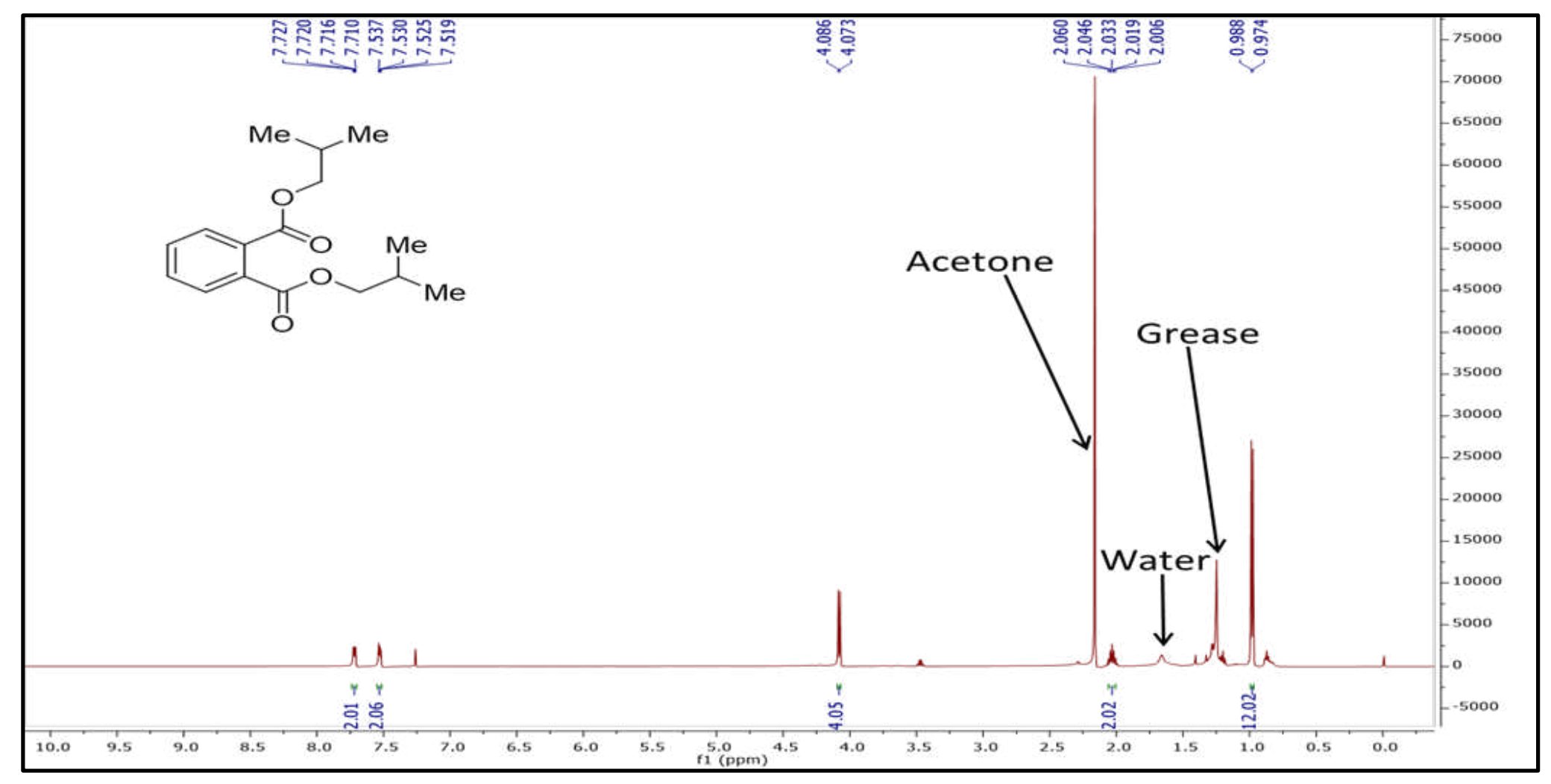

Figure 3. ${ }^{1} \mathrm{H}$ NMR of the $O b D 1$ from Obea fraction of $O$. bracteata. 


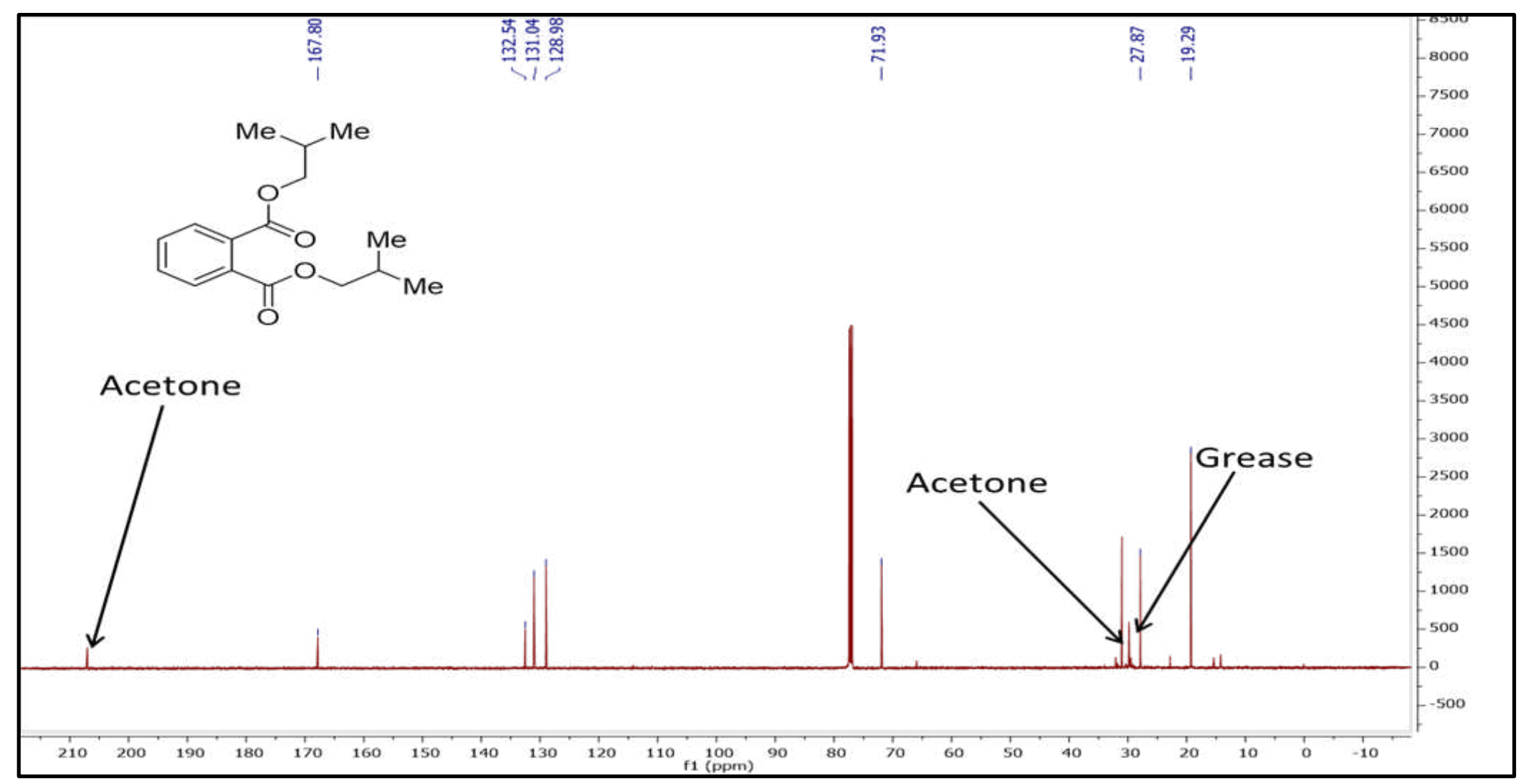

Figure 4. ${ }^{13} \mathrm{C}$ NMR of the $O b D 1$ from Obea fraction of $O$. bracteata. 


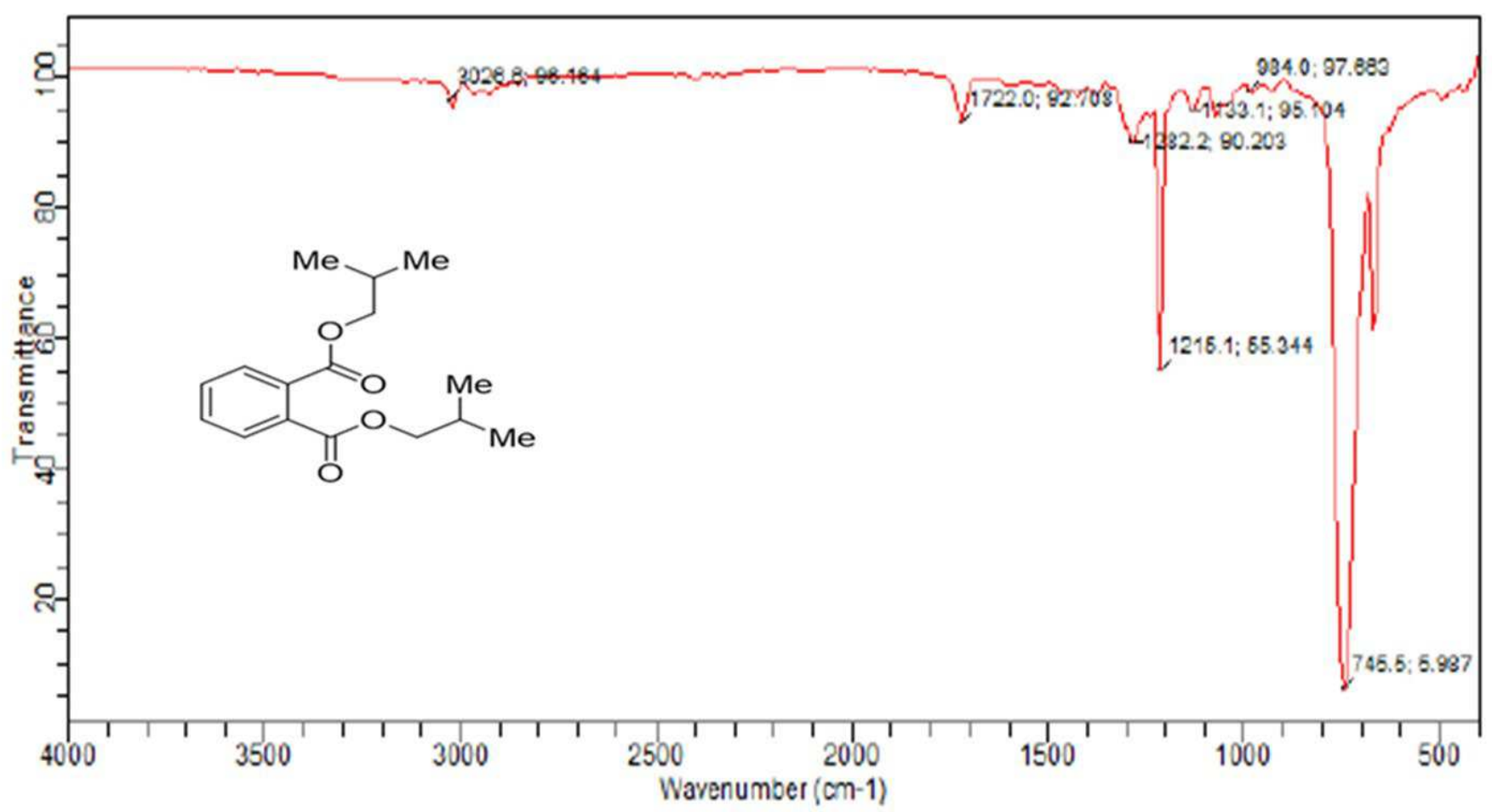

Figure 5. FT-IR (Fourier-transform infrared) spectrum of the $O b D 1$ isolated from Obea fraction of $O$. bracteata. 


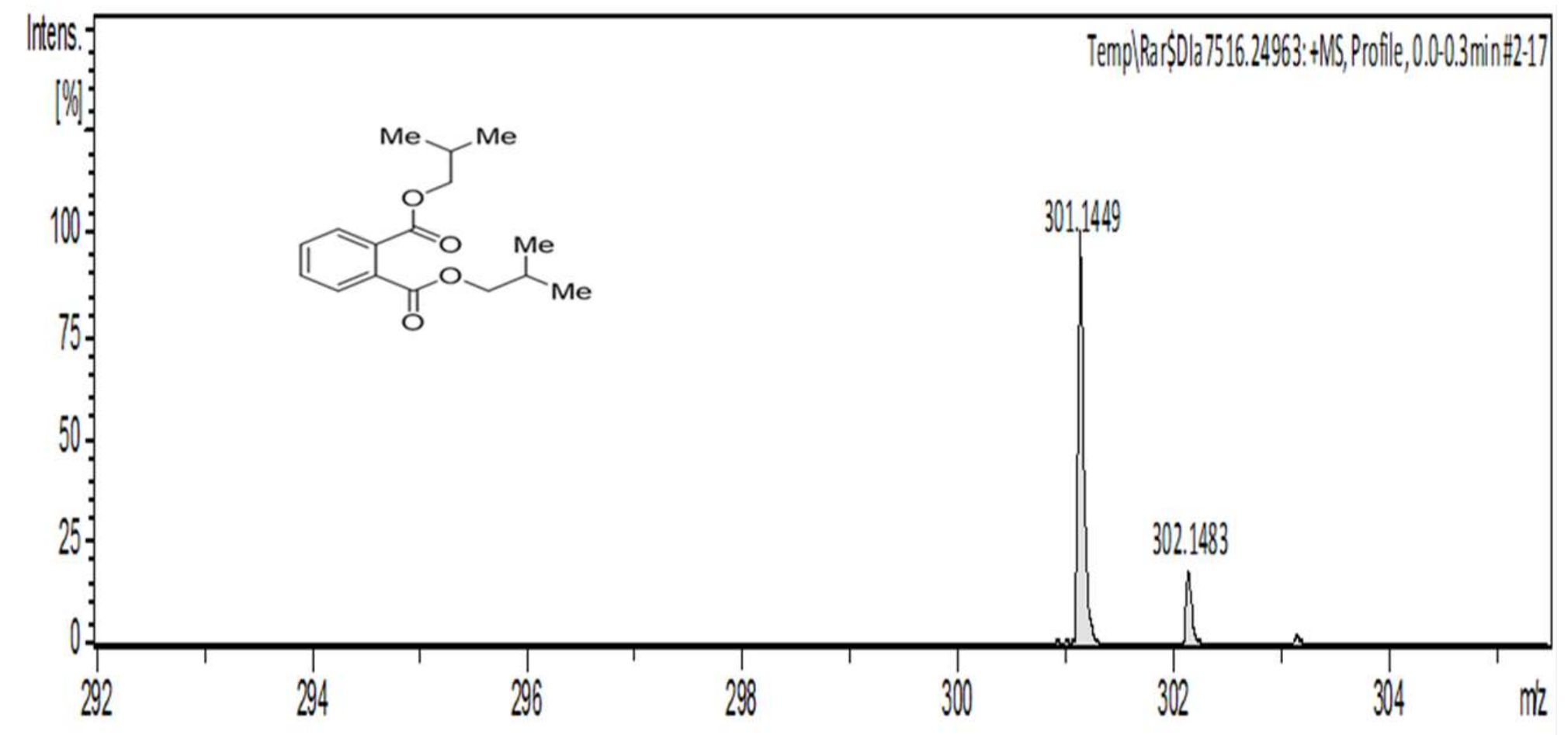

Figure 6. The HRMS (High-Resonance Mass Spectroscopy) chromatogram of ObD1 isolated from Obea of O. bracteata. 


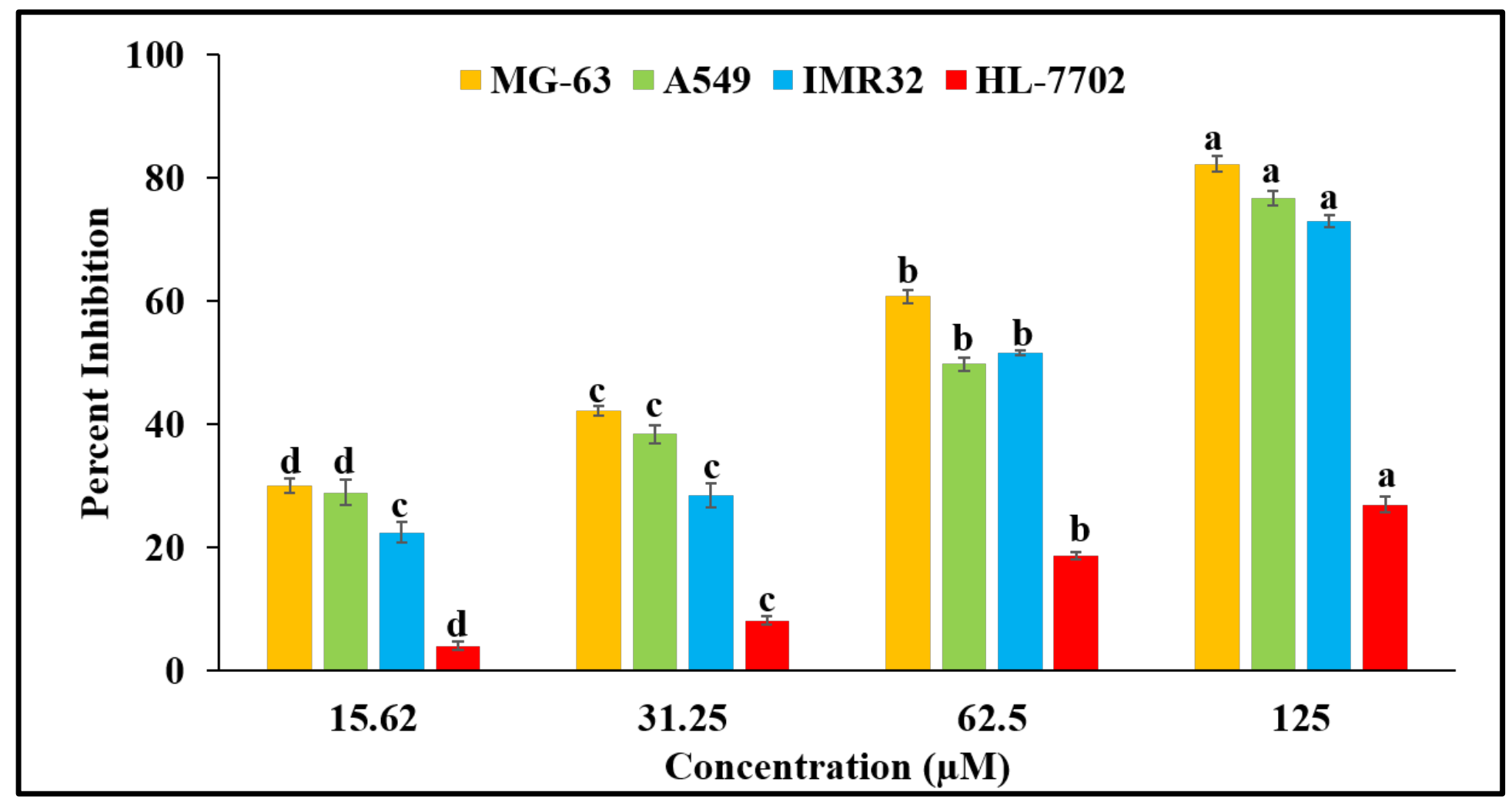

Figure 7. Cytotoxic potential of ObD1 obtained from Obea of $O$. bracteata on MG-63, A549, IMR32 and HL-7702 cells after 24 h of treatment. Values are expressed as Mean $\pm \mathrm{SE}$ at level of significance $\mathrm{p} \leq 0.05$. Data labels with different letters represent significant difference among them. 


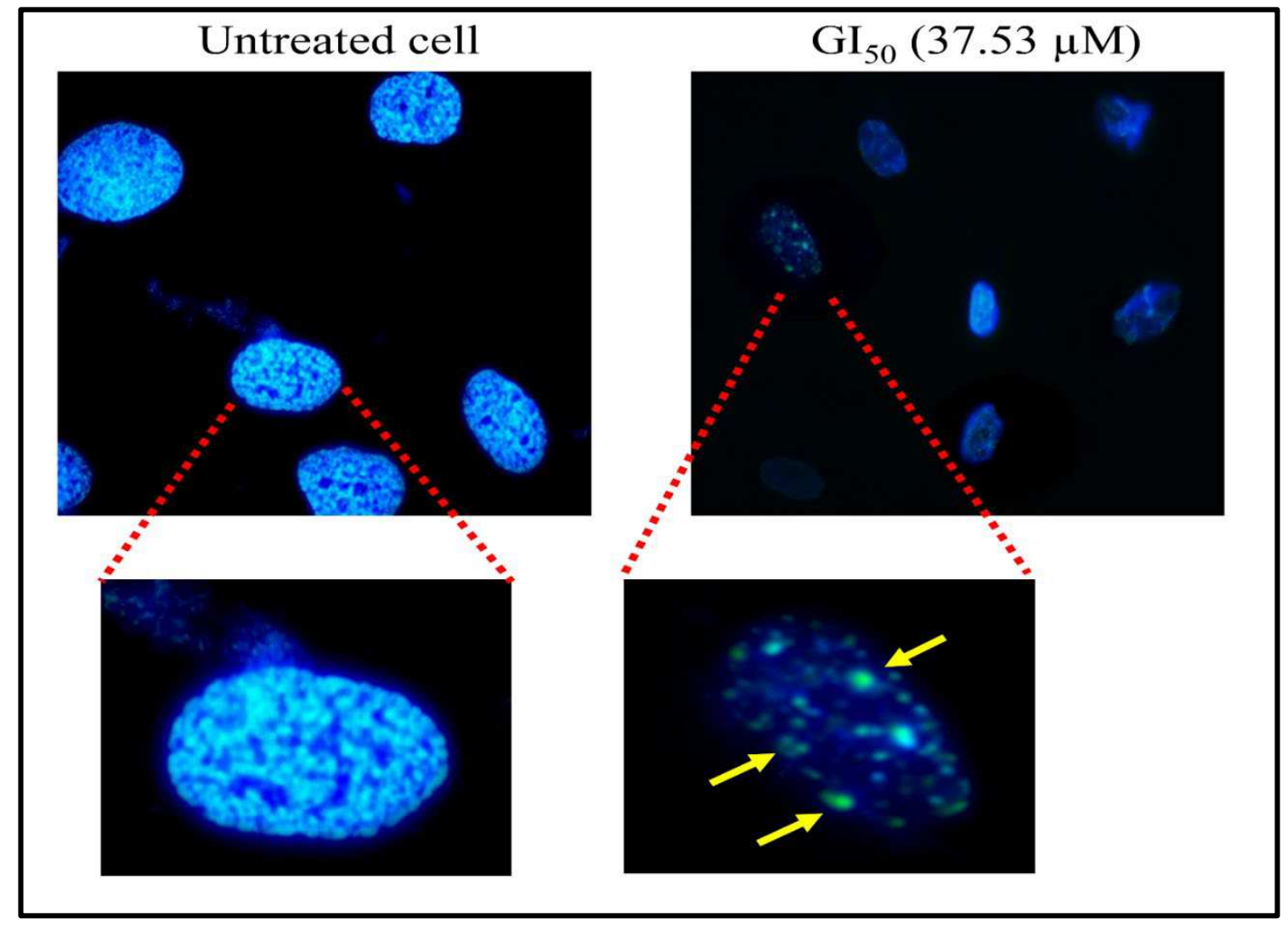

Figure 8. Confocal micrographs of DAPI stained MG-63 cells treated with $O b D 1$ from $O$. bracteata for 24 h. Arrows show nuclear condensation/fragmentation and formation of apoptotic bodies at a magnification $100 \times$ oil immersion objective lens. 


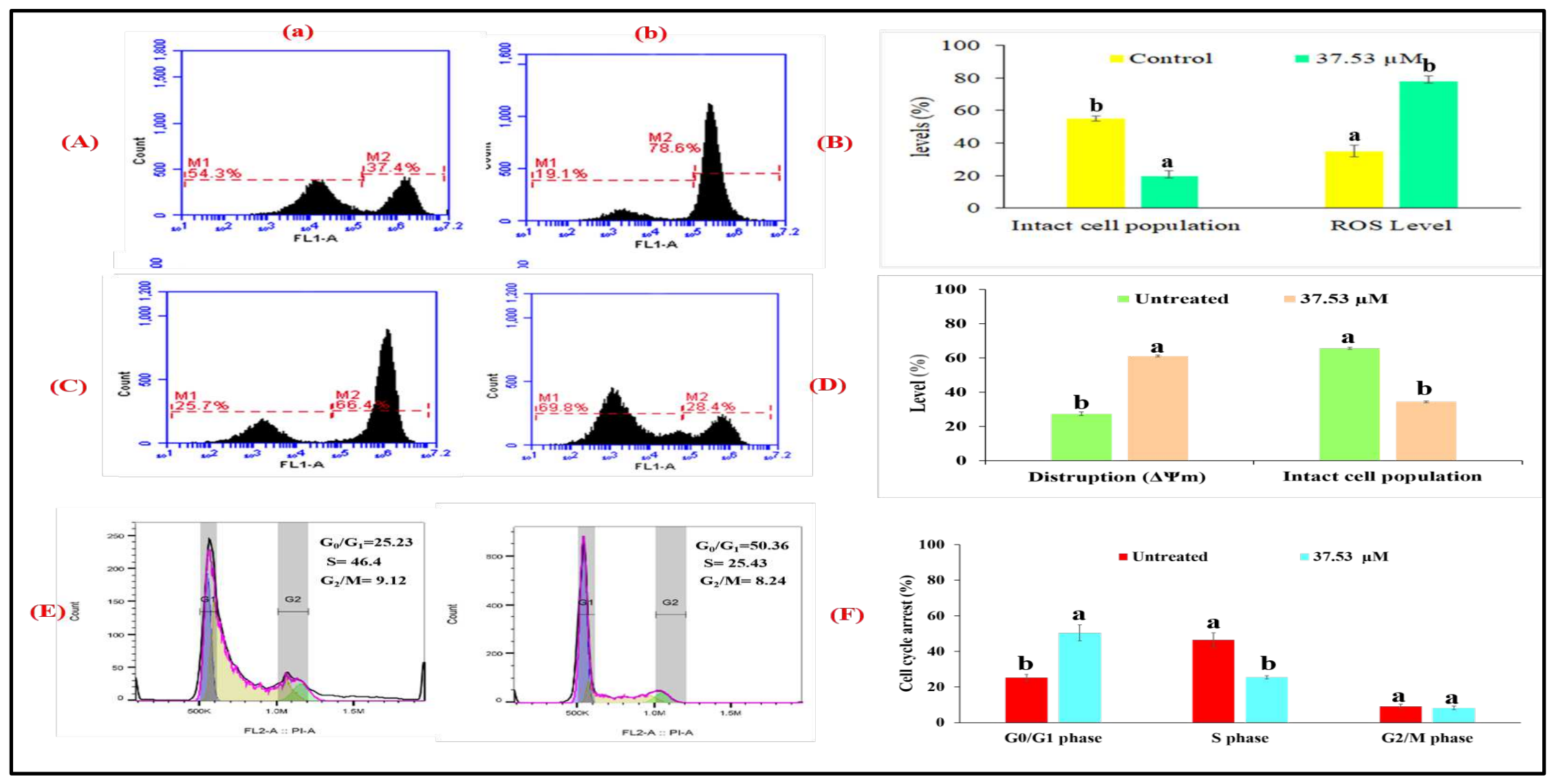

Figure 9. (A) The generation of intracellular ROS in MG-63 detected by DCFH-DA staining (M1 represents intact cell population and M2 represents cells with accumulation of intracellular ROS) (B) Histogram showing generation of intracellular ROS in MG-63 cells (24 h) exposed to ObD1 from O. bracteata. (C) The disruption of mitochondrial membrane potential $(\Delta \Psi \mathrm{m})$ in $\mathrm{Mg}-63 \mathrm{cells}$ detected by staining with Rhodamine 123 (M1 represents cells with the disruption of $\Delta \Psi \mathrm{m}$ and M2 represents the intact cells.). (D) Histogram showing disruption of mitochondrial membrane potential $(\Delta \Psi \mathrm{m})$ in MG-63 cells $(24 \mathrm{~h})$ exposed to ObD1 from O. bracteata. (E) The treatment of $O b D 1$ from $O$. bracteata $(24 \mathrm{~h})$ induced cell cycle arrest at $\mathrm{G}_{0} / \mathrm{G}_{1}$ phase in MG-63 cells detected by Cell cycle analysis kit. (F) Histogram showing different phases of $\mathrm{G}_{0} / \mathrm{G}_{1}, \mathrm{~S}, \mathrm{G}_{2} / \mathrm{M}$ in MG-63 cells using flow cytometer. (a) Untreated MG-63 cells, (b) MG63 cells treated with $O b D 1(37.53 \mu \mathrm{M})$ for $24 \mathrm{~h}$. Data labels with different letters represent significant difference among them at $(\mathrm{p} \leq$ $0.05)$. 


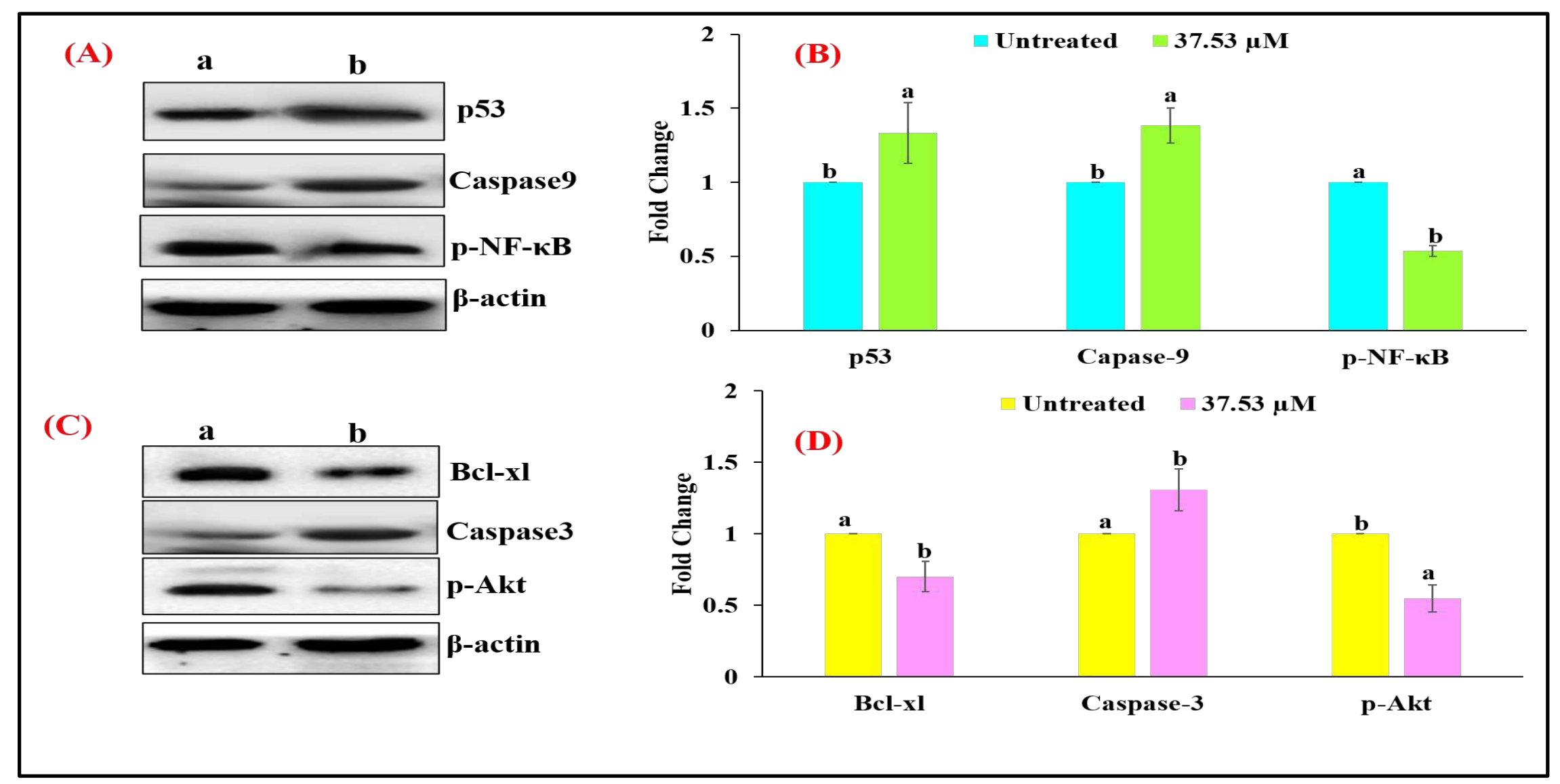

Figure 10. (A) Expression level p-53, Caspase-9 and NF- $\kappa$ B protein in MG-63 cells as detected using Western blotting. (B) Bar diagram showing densitometric analysis of p-53, Caspase- 9 and p-NF- $\kappa \mathrm{B}$ protein bands in western blotting in ObD1 treated and untreated MG63 cells. (C) Expression level of Bcl-xl, Caspase-3 and p-Akt protein in MG-63 cells. (D) Bar diagrams showing densitometric analysis of Bcl-xl, Caspase-3 and p-Akt protein bands in western blotting. (a) Untreated MG-63 cells, (b) MG-63 cells treated with ObD1 (37.53 $\mu \mathrm{M}$ ) for $24 \mathrm{~h}$ Band density was measured and normalized to that of $\beta$-actin. Values are expressed as mean \pm SE. Data labels with different letters represent significant difference among them at $(\mathrm{p} \leq 0.05)$. 


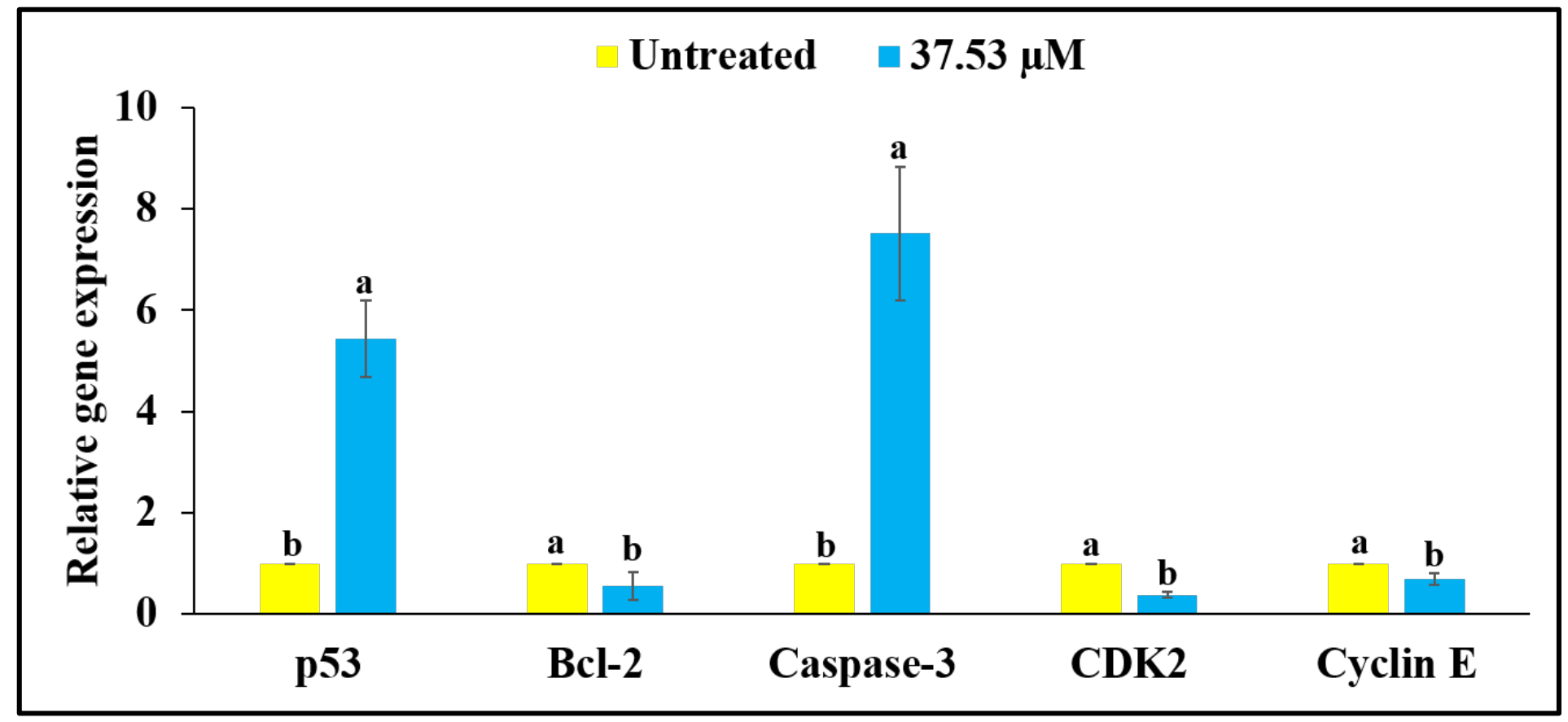

Figure 11. Effect of ObD1 from O. bracteata on the gene expression for p53, Bcl-2, Caspase-3, CDK2 and Cyclin E genes in MG-63 cells as detected using RT-PCR. Values are expressed as mean \pm SE. Data labels with different letters represent significant difference among them at $(\mathrm{p} \leq 0.05)$. 


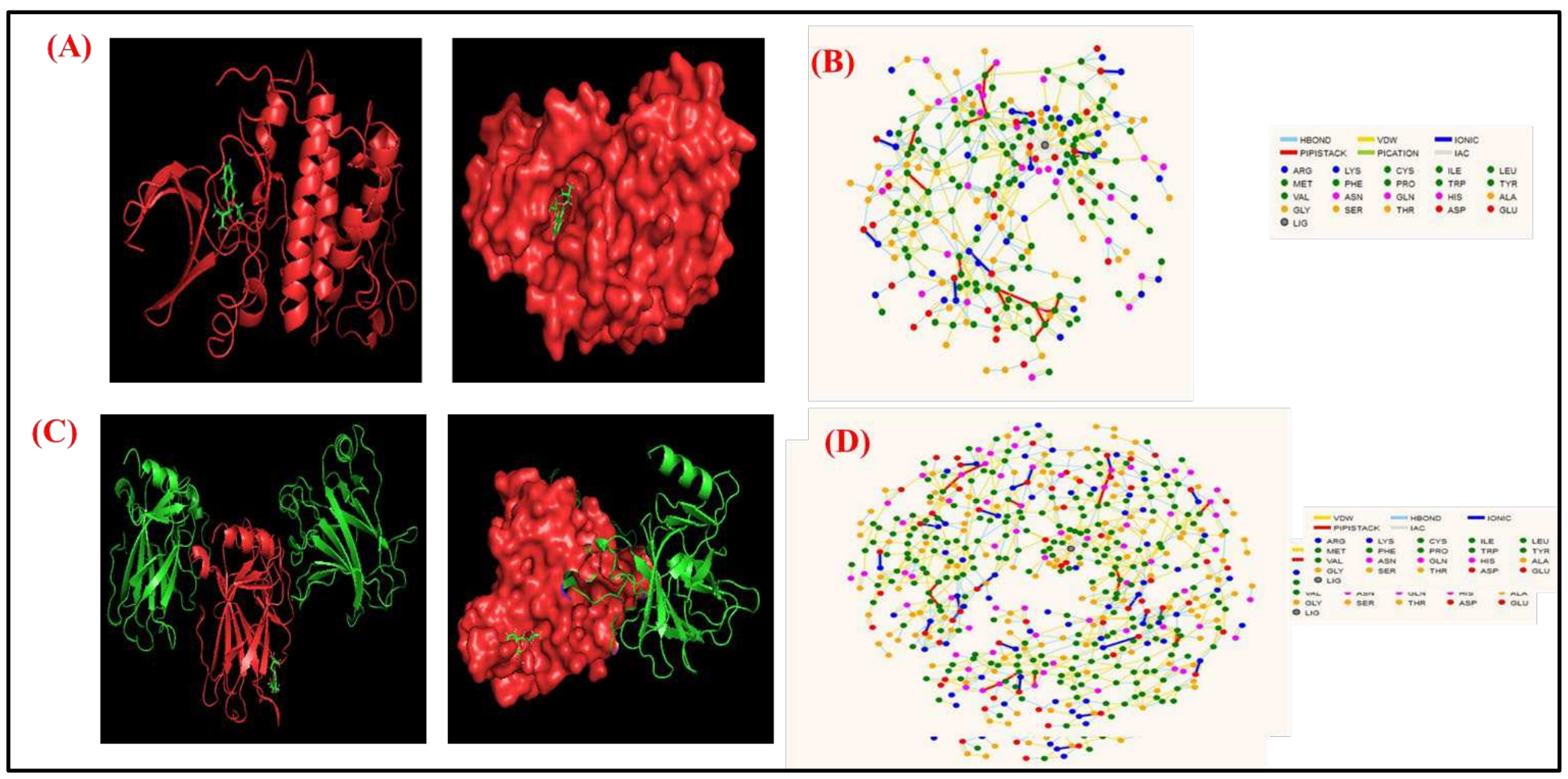

Figure 12. Docking conformations (PatchDock server) showing interaction of $O b D 1$ with minimum binding energy p-53 and CDK2 binding site, respectively (A) CDK-2 with the binding energy of $-133.96 \mathrm{kcal} / \mathrm{mol}$, (B) showed CDK2-ObD1 RIN plot, (C) p53 with the binding energy of $-151.13 \mathrm{kcal} / \mathrm{mol}$, (D) showed P53-ObD1 RIN plot. RIN analysis (RING 2.0 web server) used to showed interactions among proteins. 


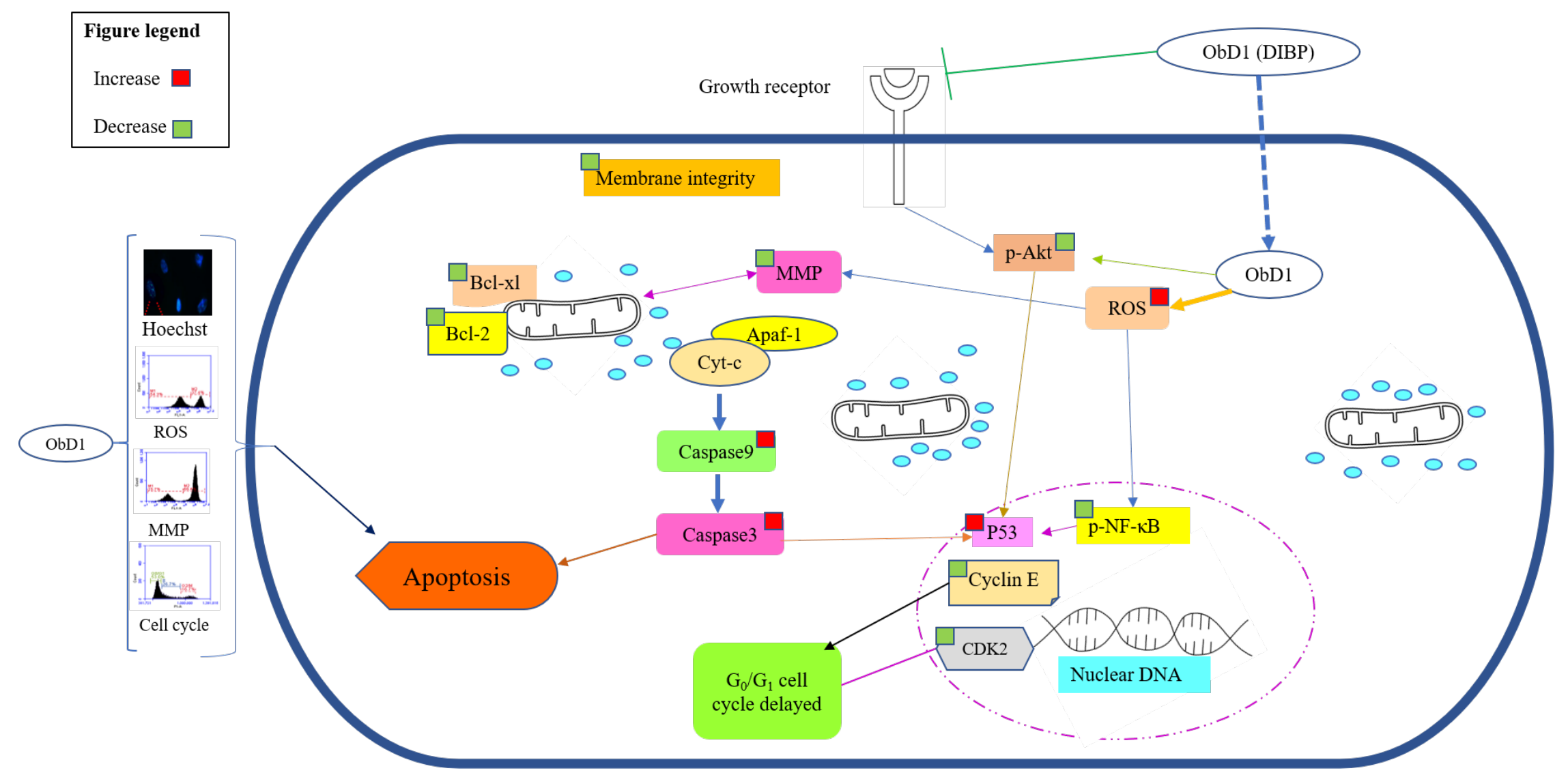

Figure 13. Schematic diagram showed the effect of $O b D 1$ isolated from Obea of Onosma bracteata induced apoptosis in osteosarcoma (MG-63 cells). 
Table 1. RT-qPCR primers sequence analysis.

\begin{tabular}{|c|c|c|c|c|}
\hline S. No. & Primer Name [Acession No.] & Product Size & Oligonucleotides $\left(5^{\prime}-3^{\prime}\right)$ sequence & Source \\
\hline 1. & p53 [NM_000546.5] & 199 & $\begin{array}{l}\text { Forward-TCACTGAAGACCCAGGTCCA } \\
\text { Reverse -TTGGCTGTCCCAGAATGCAA }\end{array}$ & NCBI \\
\hline 2. & Bcl-2 [NM_000633.2] & 123 & $\begin{array}{l}\text { Forward-AGTCTGGGAATCGATCTGGA } \\
\text { Reverse-GGCAACGATCCCATCAATCT }\end{array}$ & NCBI \\
\hline 3. & Cyclin E [NM_001238.3] & 150 & $\begin{array}{l}\text { Forward- GGTATCAGTGGTGCGACATAG } \\
\text { Reverse- CCAAGCTGTCTCTGTGGGTC }\end{array}$ & NCBI \\
\hline 4. & CDK2 [NM_001798] & 180 & $\begin{array}{l}\text { Forward- GGCCCTATTCCCTGGAGATTC } \\
\text { Reverse- CGTCCATCTTCATCCAGGGG }\end{array}$ & NCBI \\
\hline 5. & $\beta$-actin [T25383] & 166 & $\begin{array}{l}\text { Forward- GTCCTCTCCCAAGTCACACA } \\
\text { Reverse- GCTCATACATCTCAAGTTGGGAC }\end{array}$ & NCBI \\
\hline
\end{tabular}


Table 2. Antioxidant activity of extract/fractions of $O$. bracteata in Superoxide anion radical scavenging assay.

\begin{tabular}{|c|c|c|c|c|c|c|}
\hline \multirow{2}{*}{$\begin{array}{l}\text { Conc } \\
(\mu \mathrm{g} / \mathrm{ml})\end{array}$} & \multicolumn{6}{|c|}{ Scavenging (\%) } \\
\hline & Rutin & Obhex & Obcl & Obea & Obbu & Obaq \\
\hline 25 & $39.36 \pm 2.60^{c}$ & $16.85 \pm 2.18^{d}$ & $18.33 \pm 1.21^{\mathrm{d}}$ & $13.77 \pm 2.99^{d}$ & $14.76 \pm 3.18^{d}$ & $15.62 \pm 1.51^{\mathrm{d}}$ \\
\hline 50 & $43.91 \pm 2.93^{\mathrm{c}}$ & $30.87 \pm 1.79^{c}$ & $31.61 \pm 2.23^{\mathrm{c}}$ & $30.01 \pm 3.39^{\mathrm{c}}$ & $22.88 \pm 2.10^{d}$ & $19.43 \pm 2.28^{d}$ \\
\hline 100 & $74.29 \pm 1.09^{b}$ & $50.80 \pm 1.57^{b}$ & $52.40 \pm 1.82^{b}$ & $57.81 \pm 1.81^{b}$ & $41.21 \pm 1.25^{\mathrm{c}}$ & $29.64 \pm 1.66^{\mathrm{c}}$ \\
\hline 200 & $77.74 \pm 1.45^{b}$ & $59.78 \pm 1.69^{\mathrm{a}}$ & $62.85 \pm 1.98^{a}$ & $69.61 \pm 3.09^{b}$ & $57.32 \pm 0.68^{b}$ & $39.11 \pm 2.06^{b}$ \\
\hline 400 & $90.16 \pm 1.07^{\mathrm{a}}$ & $66.05 \pm 0.56^{\mathrm{a}}$ & $71.71 \pm 3.25^{\mathrm{a}}$ & $85.36 \pm 2.60^{\mathrm{a}}$ & $66.67 \pm 1.09^{\mathrm{a}}$ & $59.04 \pm 0.56^{\mathrm{a}}$ \\
\hline $\mathrm{EC}_{50}(\mu \mathrm{g} / \mathrm{ml})$ & 46.18 & 132.23 & 114.30 & 95.12 & 160.47 & 310.91 \\
\hline $\begin{array}{l}\text { Regression } \\
\text { equation }\end{array}$ & $y=19.53 \ln (x)-24.88$ & $y=18.37 \ln (x)-39.71$ & $y=19.91 \ln (x)-44.31$ & $y=26.37 \ln (x)-70.12$ & $y=19.94 \ln (x)-51.28$ & $y=15.36 \ln (x)-38.19$ \\
\hline $\mathbf{r}$ & 0.961 & 0.980 & 0.988 & 0.991 & 0.992 & 0.967 \\
\hline F-ratio & $125.18^{*}$ & $155.21^{*}$ & $100.34 *$ & $106.01 *$ & $136.74 *$ & $102.67 *$ \\
\hline HSD & 9.27 & 7.68 & 10.26 & 13.19 & 8.78 & 8.00 \\
\hline
\end{tabular}

Significance level $\left({ }^{*} p \leq 0.05\right)$.

Values expressed as mean $\pm \mathrm{SE}$.

Means with different superscripts alphabets represent significantly different values.

Obhex (hexane fraction); $\mathrm{Obcl}$ (chloroform fraction); Obea (ethyl acetate fraction); Obbu (butanol fraction); Obaq (aqueous fraction) 
Table 3. Antioxidant activity of extract/fractions of $O$. bracteata in Lipid peroxidation assay.

\begin{tabular}{|c|c|c|c|c|c|c|}
\hline \multirow{2}{*}{$\begin{array}{l}\text { Conc } \\
(\mu \mathrm{g} / \mathrm{ml})\end{array}$} & \multicolumn{6}{|c|}{ Scavenging (\%) } \\
\hline & Rutin & Obhex & Obcl & Obea & Obbu & Obaq \\
\hline 25 & $20.06 \pm 1.36^{\mathrm{e}}$ & $7.91 \pm 1.14^{\mathrm{e}}$ & $11.38 \pm 1.85^{d}$ & $16.50 \pm 2.10^{\mathrm{e}}$ & $9.79 \pm 2.18^{d}$ & $8.83 \pm 1.75^{\mathrm{e}}$ \\
\hline 50 & $39.12 \pm 1.76^{d}$ & $19.33 \pm 2.23^{d}$ & $19.33 \pm 2.68^{d}$ & $31.74 \pm 2.78^{d}$ & $16.28 \pm 1.06^{d}$ & $16.92 \pm 0.99^{d}$ \\
\hline 100 & $59.28 \pm 3.48^{c}$ & $37.73 \pm 4.22^{c}$ & $39.05 \pm 3.91^{c}$ & $63.23 \pm 2.80^{c}$ & $38.74 \pm 1.69^{c}$ & $38.51 \pm 1.62^{c}$ \\
\hline 200 & $75.09 \pm 3.73^{b}$ & $69.68 \pm 1.54^{b}$ & $68.73 \pm 1.01^{b}$ & $77.32 \pm 2.32^{b}$ & $58.55 \pm 1.51^{b}$ & $58.96 \pm 1.32^{b}$ \\
\hline 400 & $89.88 \pm 0.83^{a}$ & $90.23 \pm 0.44^{\mathrm{a}}$ & $90.55 \pm 2.50^{\mathrm{a}}$ & $91.50 \pm 1.04^{\mathrm{a}}$ & $92.30 \pm 1.19^{a}$ & $92.84 \pm \mathbf{0 . 9 5}^{\mathrm{a}}$ \\
\hline $\mathrm{EC}_{50}(\mu \mathrm{g} / \mathrm{ml})$ & 76.77 & 117.52 & 114.30 & 80.67 & 125.79 & 127.03 \\
\hline $\begin{array}{l}\text { Regression } \\
\text { equation }\end{array}$ & $y=25.33 \ln (x)-59.97$ & $y=31.01 \ln (x)-97.84$ & $y=29.96 \ln (x)-92.19$ & $y=28.21 \ln (x)-73.88$ & $y=29.91 \ln (x)-94.58$ & $y=30.02 \ln (x)-95.40$ \\
\hline $\mathbf{r}$ & 0.997 & 0.987 & 0.983 & 0.988 & 0.976 & 0.975 \\
\hline F-ratio & $121.80 *$ & $222.03 *$ & $167.18 *$ & $195.39 *$ & $450.18 *$ & $604.67 *$ \\
\hline HSD & 11.75 & 10.76 & 12.03 & 10.43 & 7.37 & 6.38 \\
\hline
\end{tabular}

Significance level $\left({ }^{*} p \leq 0.05\right)$.

Values expressed as mean \pm SE.

Means with different superscripts alphabets represent significantly different values.

Obhex (hexane fraction); Obcl (chloroform fraction); Obea (ethyl acetate fraction); Obbu (butanol fraction); Obaq (aqueous fraction) 
Table 4. Cytotoxic effects of $O b D 1$ on A549, IMR-32 and MG-63 cancer cell line in MTT assay.

\begin{tabular}{|c|c|c|c|c|}
\hline \multirow{2}{*}{ Conc. $(\mu \mathrm{M})$} & \multicolumn{3}{|c|}{ Percent Inhibition (ObD1) } & \multirow[b]{2}{*}{$\begin{array}{c}\text { HL-7702 normal human } \\
\text { hepatocyte cell line }\end{array}$} \\
\hline & $\begin{array}{l}\text { A549 Lung cancer } \\
\text { cell line }\end{array}$ & $\begin{array}{c}\text { IMR-32 neuroblastoma } \\
\text { cell line }\end{array}$ & $\begin{array}{c}\text { MG-63 osteosarcoma } \\
\text { cell line }\end{array}$ & \\
\hline 15.625 & $28.99 \pm 2.09^{d}$ & $22.52 \pm 1.71^{\mathrm{c}}$ & $30.07 \pm 1.21^{\mathrm{d}}$ & $4.06 \pm 0.30^{\mathrm{d}}$ \\
\hline 31.25 & $38.40 \pm 1.45^{\mathrm{c}}$ & $28.50 \pm 1.87^{\mathrm{c}}$ & $42.27 \pm 0.82^{\mathrm{c}}$ & $8.20 \pm 0.68^{c}$ \\
\hline 62.5 & $49.77 \pm 1.11^{b}$ & $51.58 \pm 0.36^{\mathrm{b}}$ & $60.75 \pm 1.14^{\mathrm{b}}$ & $18.63 \pm 0.9^{b}$ \\
\hline 125 & $76.71 \pm 1.19^{\mathrm{a}}$ & $72.99 \pm 0.90^{\mathrm{a}}$ & $82.23 \pm 1.24^{\mathrm{a}}$ & $26.97 \pm 0.60^{\mathrm{a}}$ \\
\hline Regression equation & $y=22.39 \ln (x)-36.26$ & $5.24 \ln (\mathrm{x})-51.61$ & $y=25.03 \ln (x)-40.73$ & $y=11.30 \ln (x)-28.25$ \\
\hline $\mathbf{r}$ & 0.968 & 0.976 & 0.992 & 0.986 \\
\hline $\mathbf{G I}_{50}(\mu \mathrm{M})$ & 47.12 & 56.05 & 37.53 & 1013.35 \\
\hline $\begin{array}{c}\text { Camptothecin }\left(\mathbf{G I}_{50}\right) \\
(\boldsymbol{\mu M})\end{array}$ & 53.37 & 64.34 & 52.80 & 74.84 \\
\hline F-ratio & $186.15^{*}$ & $287.77 *$ & $412.29 *$ & $231.88^{*}$ \\
\hline HSD & 6.85 & 6.16 & 5.07 & 3.07 \\
\hline
\end{tabular}

